ICEC - INSTITUTO CUIABÁ DE ENSINO E CULTURA

YVINNA PATRÍCIA SILVA SOUZA

PRIVATIZAÇÃO DO SISTEMA PENITENCIÁRIO

CUIABÁ - MT 
ICEC - INSTITUTO CUIABÁ DE ENSINO E CULTURA

YVINNA PATRÍCIA SILVA SOUZA

\section{PRIVATIZAÇÃO DO SISTEMA PENITENCIÁRIO}

Trabalho de conclusão de curso para obtenção do título de graduação em Direito, apresentado ao Instituto Cuiabá de Ensino e Cultura - ICEC, sob orientação do Prof. Adriano da Silva Félix.

CUIABÁ - MT 


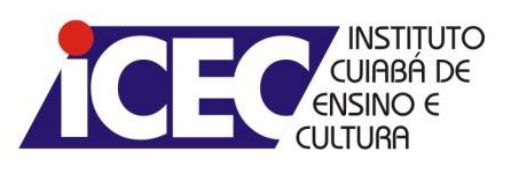

ICEC - INSTITUTO CUIABÁ DE ENSINO E CULTURA

\author{
YVINNA PATRÍCIA SILVA SOUZA
}

Trabalho de conclusão de curso para obtenção do título de graduação em Direito, apresentado ao Instituto Cuiabá de Ensino e Cultura - ICEC, sob orientação do Prof. Adriano da Silva Félix.

Aprovada em:

BANCA EXAMINADORA

PROFESSOR:

Instituto Cuiabano de Ensino e Cultura - ICEC.

PROFESSOR:

Instituto Cuiabano de Ensino e Cultura - ICEC.

PROFESSOR:

Instituto Cuiabano de Ensino e Cultura - ICEC

CUIABÁ - MT 


\section{Dedicatória}

Dedico este trabalho primeiramente a Deus, pois sem Ele, nada seria possível .

Aos meus pais Sebastião e Dinalva; pelo esforço, dedicação e compreensão, em todos os momentos desta e de outras caminhadas.

Às minhas irmãs Evelyn e Yanne; que sempre foram minhas companheiras e conselheiras 
Agradecimentos

Aos professores, especialmente ao Professor Adriano Félix pela contribuição e orientação para o desenvolvimento dessa monografia, e principalmente pela dedicação e empenho que demonstrou no decorrer das suas atividades.

Ao coordenador do curso Teófilo Márcio de Arruda Barros Júnior que desempenhou um papel fundamental nesses cinco anos do período acadêmico, sempre resolvendo os problemas que surgiam.

Aos meus colegas, pelo companheirismo, nessa jornada e busca pelo direito.

$\grave{A}$ todos aqueles que, direta ou indiretamente, colaboraram para que este trabalho consiga atingir aos objetivos propostos. 
"Educai as crianças e não será preciso punir os homens." 


\section{SUMÁRIO}

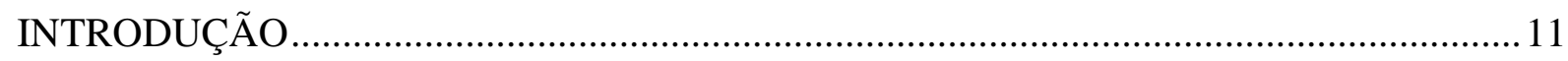

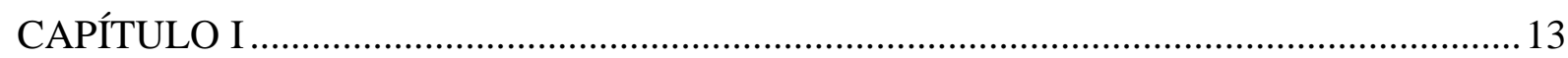

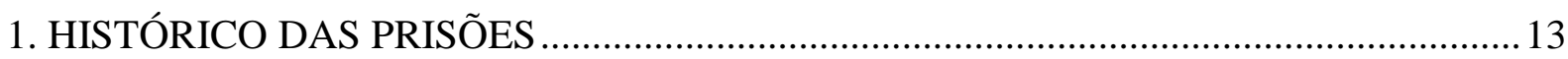

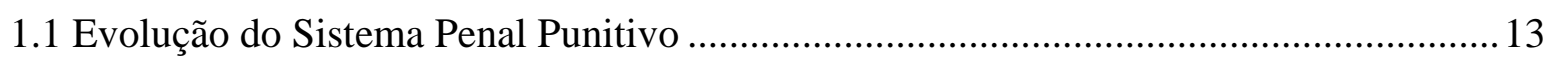

1.2 Os Sistemas Penitenciários Clássicos ....................................................................... 16

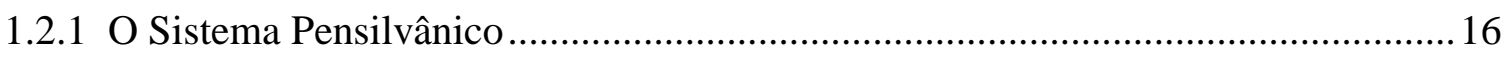

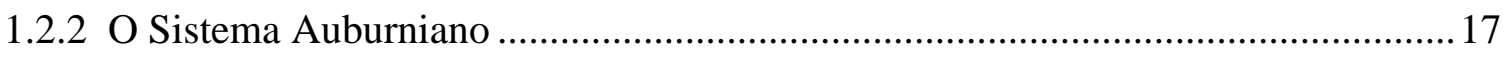

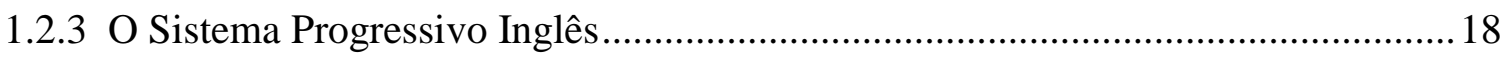

1.2.4 O Sistema Progressivo Irlandês............................................................................ 19

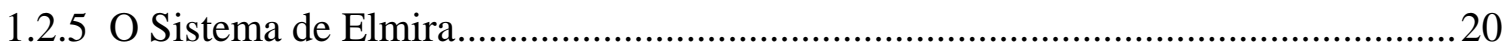

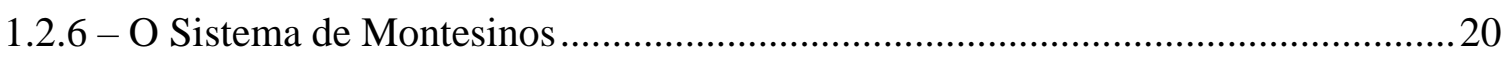

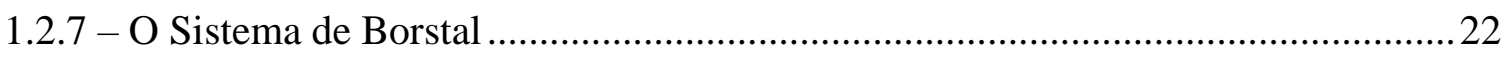

1.3 Privatização dos Presídios. Surge um novo conceito........................................................22

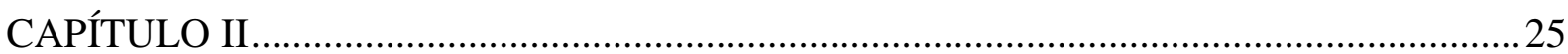

MODELOS DE PRIVATIZAÇÃO DO SISTEMA PENITENCIÁRIO NO MUNDO_............25

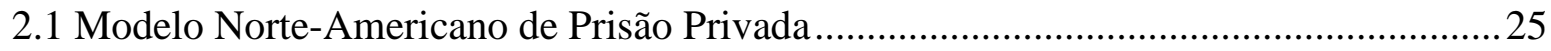

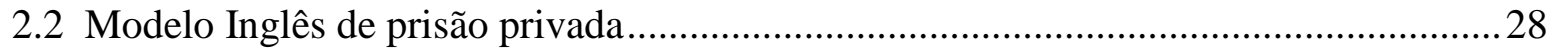

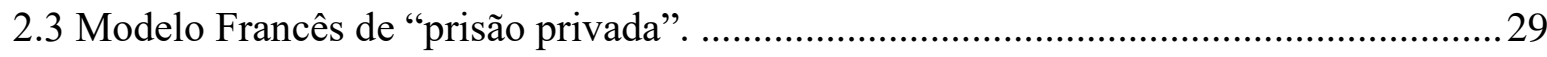

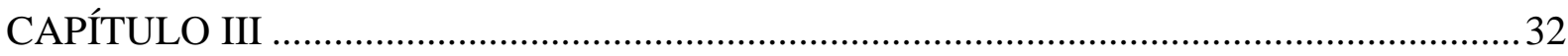

A PRIVATIZAÇÃO DO SISTEMA PENITENCIÁRIO BRASILEIRO .................................... 32

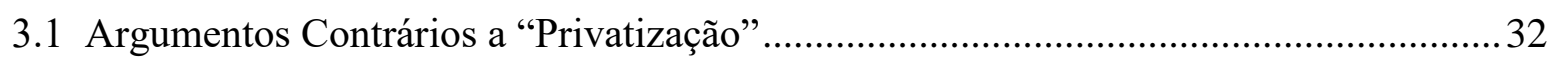

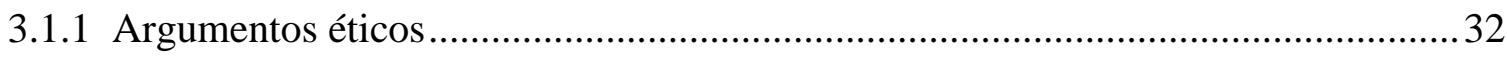

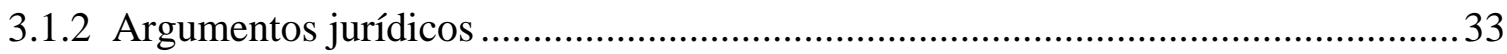

3.1.3 Argumentos Políticos ...................................................................................... 35

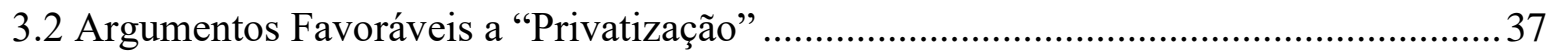

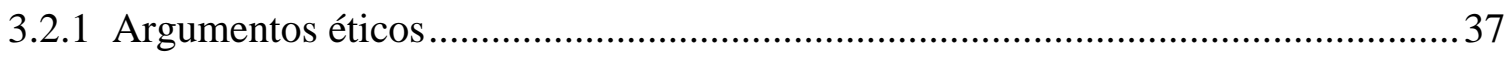

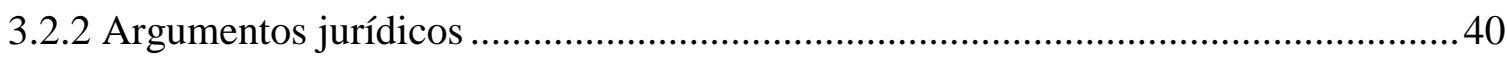

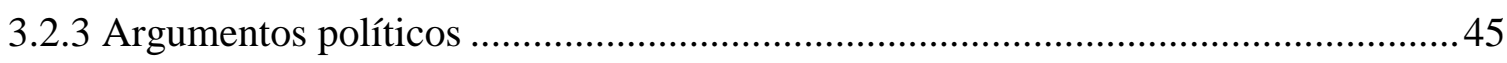




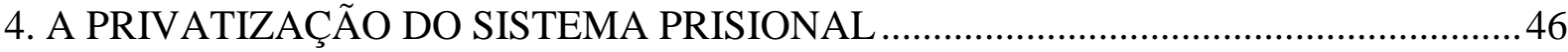

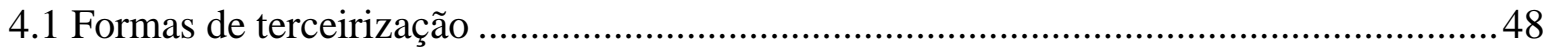

4.2 Privatização do Sistema Prisional Adotado em outros Estados Brasileiros e Países...... 50

4.3 As Empresas que atuam na Administração de Unidades Prisionais ................................52

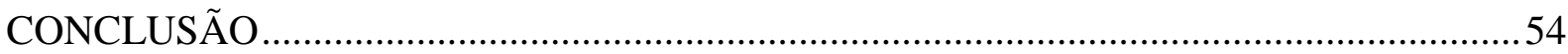

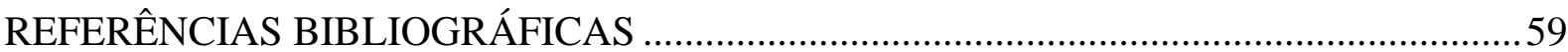




\section{RESUMO}

Este trabalho apresenta a privatização do sistema penitenciário, modelo de administração penitenciária que vem destacando como uma alternativa de melhoria do sistema penitenciário brasileiro. Nosso sistema tradicional infelizmente não tem mais controle e nem condições de tomar atitudes de acabar com o mal enraizado nas prisões. $O$ sistema privado de penitenciárias, modelo adotado em vários países como Estados Unidos, Inglaterra, França e outros, têm encontrado no Brasil algumas restrições devido a lei vigente que não autoriza a privatização total dos presídios. Mas de acordo com o modelo Francês onde o Estado trabalha em parceria com a empresa privada, numa co-gestão, é possível a transferência da administração das prisões, sem que isso implique na retirada da função jurisdicional do Estado, a qual é indelegável. A iniciativa privada se encarrega de serviços como hotelaria, alimentação, vestuário, limpeza e outros serviços descritos em contrato. $\mathrm{O}$ trabalho do detento é utilizado mediante remuneração e remissão da pena. A educação também é destaque em presídios terceirizados. Defende-se no presente estudo a privatização de presídios brasileiros, acabando com a ociosidade dos presos, profissionalizando e preparando para a reintegração na sociedade.

Palavras-chave: Tradicional - Privatização - Terceirização - Sistema Prisional. 


\begin{abstract}
This paper presents the privatization of the system penitentiary, prison management model which is highlighted as an alternative for improving the Brazilian penitentiary system. Our system Traditional unfortunately no longer has control of, or able to take the model adopted in various countries United States, Britain, France and others have found in Brazil due to some restrictions law orce that does not authorize the outright privatization of prisons. But according to the French model where the State works in partnership with private enterprise, a co-management, it is possible to transfer the administration prisons, without involving the withdrawal of courts of the State, which is inalienable. The private enterprise is responsible for services such as hospitality, food, clothing, cleaning and other services described in the contract. The work of inmate is used for remuneration and remission of sentence. The education is also featured in prisons outsourced.

It is argued in this study the privatization of Brazilian prisons, ending the idleness of prisoners, professionalized and preparing for reintegration into society.
\end{abstract}

Keywords: Traditional - Privatization - Outsourcing - Prison. 


\section{INTRODUÇÃO}

Este trabalho tem a importância de apresentar uma alternativa de proposta para ser analisada pelas autoridades competentes com o fito de proporcionar novas idéias e fundamentações para a discussão da implantação mais acentuada à privatização nos presídios brasileiros.

Através dessa proposta começaremos o trabalho abordando no capítulo I, a evolução do sistema penitenciário desde os seus primórdios, expondo que na sociedade moderna a prisão era vista como Instituição e forma punitiva através da privação de liberdade e da reclusão do apenado dentro de uma estrutura carcerária de um sistema penitenciário, apresentado como opção humanizante em relação ao sistema punitivo vigente até os fins do século XVII, que tinha por base os suplícios e as penalidades corporais, desde a sua implantação demonstrou-se ineficiente e incompatível para cumprir seus propósitos legalmente formalizados, principalmente aos que se referem à reinserção do condenado à sociedade numa perspectiva de ressocialização daquele.

Com efeito, a prisão com suas inegáveis falhas e deficiências no cumprimento das funções que legalmente lhe são atribuídas, ao longo de sua existência sempre foi alvo das mais variadas críticas. Na atualidade, entretanto, abriu-se uma enorme distância entre os conflitos e contradições, entre estrutura prisional e os seus resultados concretos com os resultados que delas são esperados em decorrência de sua finalidade legalmente formalizada.

O declínio do nosso sistema penitenciário, assim como em vários países, fundamenta-se basicamente, nos custos crescentes do encarceramento e na falta de investimentos no setor por parte da administração pública gerando uma conseqüente superlotação das prisões. A partir dessas questões, decorrem problemas como, a falta de higiene, o regime alimentar deficiente, a falta de leitos, as deficiências no serviço médico, o elevado índice de consumo de drogas, a corrupção, os reiterados abusos sexuais, o ambiente propício à violência, a quase ausência de perspectivas de reintegração social e a inexistência de uma política ampla e inteligente para o setor.

Portanto, necessário se faz, analisar alguns modelos penitenciários de terceirização no Brasil e países onde foram adotados, verificando a eficiência de resultados. Como abordaremos no capítulo II, onde nos Estados Unidos e na Europa as prisões 
privatizadas possuem aspectos interessantes, onde a direção é pública, sendo os demais serviços prestados pela iniciativa privada.

No capítulo III veremos que não apenas tem-se aumentado as críticas dirigidas contra o Sistema Penitenciário atual, como também tem conduzido a idéia de que o mesmo se encontra em crise, necessitando de um Sistema Prisional reformulado e diverso do atual.

Muito embora haja questionamento em relação aos discursos da crise do sistema penitenciário, principalmente levando-se em consideração as incompatibilidades que podem ser encontradas entre o Sistema punitivo carcerário e as funções legais que se propõe a cumprir, é inegável que o debate acerca do assunto, tem fomentado as mais diversas propostas.

A questão deve sem dúvida ser minuciosamente analisada, as questões referentes à viabilidade não podem ser esquecidas, o que não se pode é desprezar uma real alternativa de solução, ou pelo menos moderação da atual crise. O sistema prisional brasileiro atingiu o seu limite.

Através dos estudos e adoções de novas alternativas para a pena de prisão é que surgiu uma das mais recentes e controvertidas idéias a de privatização que será abordada ao final deste trabalho.

A verdadeira finalidade da prisão parece ter sido esquecida. Ressocializar a pessoa presa, nas situações atuais é tarefa impossível, pois hoje é fato comprovado que as penitenciárias em vez de recuperar os presos, os tornam piores e menos propensos a se reintegrarem ao meio social.

Diante desta realidade é que chegamos a seguinte indagação: $O$ atual sistema prisional brasileiro tem mostrado ser capaz de ressocializar a pessoa presa? 


\section{CAPÍTULO I}

\section{HISTÓRICO DAS PRISÕES}

\subsection{Evolução do Sistema Penal Punitivo}

A prisão é velha como a memória do homem e mesmo com o seu caráter aflitivo, continua a ser o mal necessário a que se recorre em todo o mundo.

Como não existia arquitetura penitenciária própria, nos primórdios da humanidade, prendiam-se as pessoas pelos pés, pelas mãos, pelo pescoço, pelos braços, etc. é nas origens zoológicas que vem o uso de "prender". Cavernas, subterrâneos, túmulos, fossas, torres, troncos, tudo servia para privar a liberdade.

As civilizações mais antigas, como os Persas, os antigos Gregos e os Romanos deram ênfase ao acorrentamento e à segregação em estabelecimentos especialmente preparados para prender os infratores. A palavra cárcere, do latim carcer designava, na Idade Antiga, o local do circo em que os cavalos aguardavam o sinal para a partida, nas corridas. Passou depois a designar a prisão, onde se colocavam os escravos, os delinquientes e os vencidos na guerra. ${ }^{1}$

Não havia nesta fase da história, preocupação com a pena de privação da liberdade, e sim de preservar o réu até seu julgamento ou execução. Recorria-se à pena de morte, às penas corporais e às infamantes. Com a evolução das civilizações, o cunho da vingança privada foi acabando aos poucos, passando-se para o Poder Público a responsabilidade de penalizar o infrator. O Estado soberano passou a castigar o corpo do sentenciado em praça pública. ${ }^{2}$

Ao que se sabe, a prisão apareceu, com a característica de pena, na Idade Média, com o Direito Canônico que impunha a reclusão para os clérigos que incorressem em

\footnotetext{
${ }^{1}$ FALCONI, Romeu. Sistema Presidial: Reinserção Social? São Paulo: Ícone, 1998, p.51.

${ }^{2}$ Id. Ibid. p. 52.
} 
infrações eclesiásticas e também para os hereges e delinqüentes julgados pela jurisdição da Igreja. $^{3}$

Na Idade Média, castelos, fortalezas e conventos mantinham espaço como prisão. A Igreja, em suas leis, admitia a pena privativa de liberdade, sendo consagrado, nesse período, o termo penitenciária. ${ }^{4}$

O criminoso (pecador) aceitava e, às vezes, suplicava, como graça, a penitência. A "reabilitação" vinha da adesão íntima ao sofrimento purificador. Além dos presos julgados e condenados na esfera da jurisdição da Igreja, existiam, ainda, os penitenciais, que se recolhiam voluntariamente sob a guarda eclesiástica, para o fim de corrigir defeitos de caráter ou pagar pecados cometidos. ${ }^{5}$

Já no século XVI surgiram às galés ou galeras $^{6}$, navios que serviam de prisão onde o preso cumpria a pena de remar, com dura jornada de trabalho forçado, desaparecendo posteriormente face ao desenvolvimento das navegações.

Vieram, em seguida, os presídios militares em decorrência da necessidade de mão-de-obra para os serviços de fortificações. Dessa modalidade, passou-se para os presídios de obras públicas, aos quais se destinavam os réus condenados ao trabalho forçado em canais e prédios públicos, presos a correntes, vigiados por pessoal armado, permanecendo à noite em barracas ao ar livre. Essa tendência só não prosperou, porque gerava concorrência e até disputa com a produção do trabalhador livre, daí a preferência óbvia pelo sistema de amontoamento de prisioneiros em velhas edificações e claustros que antes serviam aos religiosos. ${ }^{7}$

Pesquisadores apontam a House of Correction, centro reeducador localizado em Londres inaugurada em 1550 como sendo a precursora do sistema penitenciário da atualidade, tendo a prisão como pena que serve de meio de reeducação. ${ }^{8}$ Posteriormente, com o mesmo escopo reeducador, foram construídas várias outras penitenciárias, espalhando-se por todo o território europeu, como Amsterdã, Bremen, Lubeck, Hamburgo e assim por diante, até se generalizarem. Ressalte-se que o pioneirismo das mencionadas penitenciárias consistiu no esforço de adotar o ideal filosófico de destinar os estabelecimentos para o específico cumprimento de pena com caráter educativo. ${ }^{9}$

\footnotetext{
${ }^{3}$ FALCONI, Romeu. Sistema Presidial: Reinserção Social? São Paulo: Ícone, 1998, p.53.

${ }^{4}$ Id, Ibid. p.55.

${ }^{5}$ GOULART, Henry. A individualização da Pena no Direito. São Paulo. Ed. Brasileira de Direito, 1975, p.52.

${ }^{6}$ OLIVEIRA, Edmundo. O Futuro Alternativo das Prisões. 1 ed., Rio de Janeiro: Forense, 2002, p.5

${ }^{7}$ Id. Ibid. p.6.

${ }^{8}$ FRAGOSO, Heleno Cláudio. Lições de Direito Penal. 7 ed., São Paulo: Forense, 1985, v.1, p.298.

${ }^{9}$ Id. Ibid. p.299.
} 
No século XVIII, graças aos talentos de John Howard e Cesare Beccaria - duas grandes personalidades da evolução histórica do Direito Penal, cujas obras causaram uma verdadeira evolução nas primeiras concepções pedagógicas da pena àquela época, especialmente porque procuraram defini-la com a utilidade, de maneira que o encarceramento só se justificaria se produzisse algum beneficio ao delinqüente e não apenas a retribuição de um mal por outro - aconteceu o início do Período Humanitário das prisões, não porque elas se tornassem verdadeiramente humanas, mas porque foram expostas ao público as verdades que todos sentiam e sussurravam em relação aos abusos, atrocidades e injustiças contra as pessoas sujeitas ao frio aprisionamento. Daí a sequência de uma série de movimentos de reforma, que se estenderam na Europa, durante os séculos XVIII e XIX, combatendo a dureza dos cárceres, a compilação dos processos investigatórios, o atraso dos aparelhos judiciários e a falta de idoneidade das prisões como local para cumprir pena ressocializadora. ${ }^{10}$

Outro momento marcante na evolução da história da prisão foi a publicação, em 1819, da obra Theory of Penaltys and Recompenses (Teoria das Penas e das Recompensas) do inglês Jeremias Bentham. Ele apresentou nova concepção de penitenciária, denominada de Penitenciary Panopticon, ${ }^{11}$ um modelo arquitetônico inovador com as celas distribuídas em forma de raios. Ele dizia que o efeito mais importante do modelo era induzir no detento um estado consciente e permanente de visibilidade que assegurasse o funcionamento automático do poder. ${ }^{12}$

Merecendo ênfase ainda, na obra de Bentham, é exposto o sentido correcional da prisão como a separação dos presos por sexo, a importância de adequada alimentação, vestuário, limpeza, trabalho, assistência á saúde, educação e ajuda aos liberados. ${ }^{13}$

As idéias de John Howard, Cesare Beccare e Jeremias Bentham ${ }^{14}$ deram origem à formação dos Regimes Penitenciários Clássicos, concebidos sob a base de sistemas diferenciados de reeducação, os quais prosperavam a partir do século XIX.

No século XX, ao chamado Período Científico da Prisão, não foi possível também se obter a certeza de que algum dia a humanidade se beneficiará com o aperfeiçoamento global das penas privativas de liberdade. Lembremos, a propósito, o quadro marcante da desmoralização da prisão retratada nos insolentes campos de concentração

\footnotetext{
${ }^{10}$ OLIVEIRA, Edmundo. O Futuro Alternativo das Prisões. 1 ed., Rio de Janeiro: Forense, 2002, p.6

${ }^{11}$ FOUCAULT, Michel. Vigiar e Punir. 11 ed., São Paulo: Vozes, 1977, p.177/178.

${ }^{12}$ FALCONI, Romeu. Sistema Presidial: Reinserção Social? São Paulo: Ícone, 1998, p.59.

${ }^{13}$ Id. Ibid., p.7.

${ }^{14}$ OLIVEIRA. Edmundo. Op. cit. p.7.
} 
projetados, na Europa, pelo plano Nazista do Terceiro Reich, liderado por Adolf Hitler, em nome de horrenda política anti-semita. ${ }^{15}$

\subsection{Os Sistemas Penitenciários Clássicos}

Portanto, como se viu, durante muitos anos a humanidade puniu seu semelhante, sem se preocupar com os critérios dessa punição, ficando o encarcerado sob o domínio das arbitrariedades dos responsáveis por suas custódias.

A ausência de uma uniformidade para tratamento do homem preso levou à criação de um movimento para que fosse estabelecido um parâmetro, um sistema de tratamento do preso, um verdadeiro sistema penitenciário. ${ }^{16}$

Cessare Beccaria, John Howard e Jeremias Bentham, através das teorias de execução das penas que sustentavam, germinaram no século XVIII, nos Estados Unidos o movimento de criação de sistemas penitenciários padronizados. ${ }^{17}$

Os Sistemas Penitenciários Clássicos, que prosperaram nos Estados Unidos e na Europa, serviram de modelo para os demais países do mundo. A partir do século XIX, foram os seguintes: Sistema Pensilvânico; Sistema Aulburniano; Sistema Progressivo Inglês; Sistema Progressivo Irlandês; Sistema de Elmira; Sistema de Montesinos e Sistema Borstal. ${ }^{18}$

\subsubsection{O Sistema Pensilvânico}

O Sistema Pensilvânico também conhecido como Sistema de Philadelphia ou Celular, foi implantado na Philadelphia - Estados Unidos, em 1829, mais precisamente na Eastern Penitentiary. ${ }^{19}$

A base do modelo Pensilvânico era o isolamento celular, com trabalho no próprio interior da cela, separando os presos para evitar a promiscuidade e fazer com que todos meditassem sobre seus crimes com o objetivo de melhora pessoal.

\footnotetext{
${ }^{15}$ FALCONI, Romeu. Sistema Presidial: Reinserção Social? São Paulo: Ícone, 1998, p.60.

${ }^{16}$ OLIVEIRA, Edmundo. O Futuro Alternativo das Prisões. 1 ed., Rio de Janeiro: Forense, 2002, p.51.

${ }^{17}$ Id, Ibid, p. 51.

${ }^{18}$ OLIVEIRA. Edmundo. Op. cit, p. 51

${ }^{19}$ Id. Ibid., p.61
} 
Durante a restrição a liberdade, a única leitura permitida era a Bíblia. O completo isolamento em relação ao mundo exterior não permitia nem mesmo receber ou enviar cartas, sendo permitidos apenas contatos com sacerdotes e funcionários da prisão. ${ }^{20}$

Sabe-se que os prisioneiros eram expostos aos olhos de visitantes para que estes pudessem vê-los em suas celas, como exemplos atemorizantes. ${ }^{21}$

Entendiam que em condições rigorosíssimas, mantendo um ambiente de ordem e disciplina, isentar-se-iam quase inteiramente de fugas e evitariam o contágio moral, a interação perversiva e criminógena, mas por outro lado causavam aos presos o desespero, o sofrimento, afetavam a saúde física e psíquica dos apenados e de modo algum os preparava para o retorno à sociedade livre. ${ }^{22}$

sendo:

José Frederico Marques, ao comentar este sistema prisional analisou-o como

"[...] de isolamento rigoroso e contínuo, produziu, porém maus resultados. O Sistema Celular agindo sobre entes geralmente inadaptados à vida social e de vontade débil, um lugar de preparar o delinquente para um promissor reingresso na sociedade, trazia como consequência, justamente o contrário do que se pretendia [...] $]^{, 23}$

A solidão foi tão cruel, no estado de espírito dos enclausurados, que muitos foram vítimas de loucura. Dessa forma, não pôde prosperar tal sistema que não se preocupava com o tratamento do preso, mas somente com a forma pouco humana de castigo, o que levou a extinguir o Sistema Pensilvânico. ${ }^{24}$

\subsubsection{O Sistema Auburniano}

O Sistema Auburniano ou "Silent System" foi implementado na Penitenciária de Auburn, em Nova Iorque, a partir do ano de 1818. Impunha o trabalho em comum durante o dia, sob absoluto silêncio, punindo com variados castigos qualquer tentativa de comunicação. À noite, o isolamento celular também era absoluto para descanso da labuta

\footnotetext{
${ }^{20}$ FALCONI, Romeu. Sistema Presidial. Reinserção Social? São Paulo : Ícone, 1998, p. 60

${ }^{21}$ Id, Ibid, p. 61

${ }^{22}$ FALCONI, Romeu. op. cit, p. 61

${ }^{23}$ MARQUES, José Frederico. Curso de Direto Penal. São Paulo: Saraiva, 1953, p. 126

${ }^{24}$ FALCONI, Romeu. op. cit, p. 61
} 
diária e como meio de evitar a corrupção dos condenados. Os presos não podiam receber visitas, nem mesmo de familiares e eram proibidos exercícios e distrações de qualquer espécie, com direito apenas a rudimentar instrução e aprendizado proporcionados pelos funcionários da prisão. ${ }^{25}$

No Sistema Auburniano, os presos eram divididos em três classes: a primeira era composta pelos delinquentes mais velhos e mais perigosos, que deveriam ficar em isolamento celular completo; a segunda era constituída pelos delinquentes que deveriam ficar trancados em suas celas, três dias por semana e a terceira abrangia os delinquentes que deveriam ficar isolados apenas um dia por semana. Nos demais dias, os delinquentes da segunda e terceira classes deveriam trabalhar em silêncio absoluto.

Esse sistema misto - que teve grande aceitação nos Estados Unidos da América -, ainda continuava lesivo pelo isolamento, pelo silêncio e pela disciplina severa, causando distúrbios emocionais e ressentimento, mas por outro lado atenuava a clausura, excluía a contaminação moral e significativa, sendo, portanto, um inegável avanço em relação ao modelo Philadélphico. As críticas ao sistema começaram, quando foram constatados vários casos de mortes provocadas pela tuberculose e pela loucura.

Os dois sistemas - Pensilvânico e Auburniano - começaram a declinar e abriram caminho para novas alternativas, que buscariam diminuir suas falhas e limitações. Surgiram, então, os sistemas progressivos, organizados em três ou quatro etapas de rigor decrescente, a conduta e o trabalho eram utilizados como meios de avaliação que preparavam o recluso gradualmente para a vida em liberdade. Obtiveram, portanto a aceitação universal, de modo que em dezenas de países, com esta ou aquela variação, emprega-se hoje a progressividade na execução da pena, tendo como escopo final o reingresso do condenado na sociedade.

\subsubsection{O Sistema Progressivo Inglês}

Surgido na Inglaterra, em 1840 foi motivado pelas deficiências correcionais e reformadoras apresentadas pelos modelos Pensilvânico e Auburniano. ${ }^{26}$

Também denominado de "Mark System", era caracterizado pela adoção de penas indeterminadas, as quais eram medidas em razão dos trabalhos realizados pelo interno,

\footnotetext{
${ }^{25}$ FRAGOSO, Heleno Cláudio. Lições de Direito Penal. 7 ed. Vol. I. São Paulo: Forense, 1985 p. 299

${ }^{26}$ OLIVEIRA, Edmundo . O futuro alternativo das prisões. Rio de Janeiro : Forense, 2002, cit. p. 52
} 
da boa conduta do condenado, e da gravidade do delito praticado. Com base nesses três fatores, eram atribuídas marcas ou vales, diariamente e ao obter determinado número dessas marcas ou vales, o condenado era posto em liberdade. ${ }^{27}$

Neste sistema, o cumprimento da pena era realizado em três períodos progressivos, daí o nome "Modelo Progressivo".

O primeiro período era chamado de período de prova, implicava em isolamento celular completo diurno e noturno, com trabalho isolado e obrigatório durante o dia, no estilo Pensilvânico. No segundo período, após atingido determinado número de marcas ou vales, ao condenado era imposto o isolamento noturno e trabalho comum sob a regra do silêncio no período diurno, no estilo Auburniano. No terceiro período, posteriormente a recebimento de novos benefícios - marcas ou vales -, o condenado depois de certo tempo e com bom comportamento, podia obter o "ticket of leave", uma espécie de livramento condicional. ${ }^{28}$

\subsubsection{O Sistema Progressivo Irlandês}

Difere o Sistema Progressivo Irlandês do Inglês em dois pontos:

Primeiramente, o Sistema Inglês contém três períodos de execução da pena, enquanto neste (Irlandês) há quatro. Surge um período intermediário entre a prisão comum segundo período do Sistema Inglês - e o livramento condicional - terceiro período do Sistema Inglês -. Esse período do intermediário, com o feito de antecedente da prisão aberta, consistia na transferência do recluso para prisões agrícolas, semi-abertas, com regime mais brando, sem uniforme e com permissão de diálogo e trabalho no campo, preparando o preso para o futuro livre com a obtenção do "ticket of leave" (liberdade condicional). ${ }^{29}$

Outro detalhe diferenciado deste sistema em relação ao Inglês residia no fato dos detidos não serem obrigados a permanecer em silêncio durante o trabalho em comum. ${ }^{30}$

O Sistema Progressivo Irlandês, pelas benéficas modificações experimentadas, no sentido de oferecer ao condenado vantagem por etapas, passou a influir, positivamente, nos

27 GOULART. Henry. A individualização da Pena no Direito Brasileiro. São Paulo: Editora Brasileira de Direito. 1975 , p. 59

${ }^{28}$ FALCONI, Romeu. Sistema Presidial. Reinserção Social? São Paulo : Ícone, 1998, p. 62

${ }^{29}$ OLIVEIRA, Edmundo . O futuro alternativo das prisões. Rio de Janeiro : Forense, 2002, cit. p. 53

${ }^{30}$ Id. Ibid, p. 54 
encarceramentos dos regimes da Europa e dos Estados Unidos da América, espalhando-se posteriormente por todos os continentes. ${ }^{31}$

\subsubsection{O Sistema de Elmira}

Surgido nos Estados Unidos, tratava-se de um Regime de Reformatório com base no Sistema Progressivo Irlandês. A denominação dada a este Sistema decorre de haver sido o Reformatório de Elmira, (localizado no estado de Nova Iorque - Estados Unidos), o mais famoso do Sistema.

Com o Reformatório de Elmira, a reação contra a criminalidade pela cura do condenado se apresenta mais claramente na evolução prática da política penitenciária.

Criou-se o Sistema Unitário de Pena e Medida de Segurança, mediante o critério de avaliação do condenado. Só admitia jovens delinqüentes entre 16 e 30 anos de idade, sujeitos a uma pena relativamente indeterminada com a fixação de um mínimo e de um máximo. Após o condenado passar por uma classificação inicial, era submetido a um sistema de marcos ou vales concedidos em razão da evolução no trabalho, boa conduta, instrução moral e religiosa. $\mathrm{O}$ aprendizado de um ofício era obrigatório e a disciplina era do tipo militar. Quando alcançava a terceira fase, o apenado tinha direito ao livramento condicional e recebia um pecúlio, como forma de ajuda financeira para as primeiras necessidades.

Em 1915, não só Elmira, mas todos os regimes de Reformatórios começaram a declinar nos Estados Unidos. As críticas mais fortes residiam no fato de que os jovens ficavam deprimidos com a rigorosa disciplina militar, castigos pesados e a um ambiente de Segurança Máxima que não condizia com o sentido teórico de reformulação moral para a regeneração do condenado. Na verdade, começava a surgir nos Estados Unidos, com repercussão na Europa, o entusiasmo pela adoção das prisões abertas. ${ }^{32}$

\subsection{6 - O Sistema de Montesinos}

O Sistema de Montesinos, nascido na Espanha, em 1985 e criado pelo Coronel Manuel Montesinos e Molina, procurou implantar um diferenciado e eficiente regime

\footnotetext{
${ }^{31}$ OLIVEIRA, Edmundo . O futuro alternativo das prisões. Rio de Janeiro : Forense, 2002, cit. p. 54

${ }^{32}$ Id. Ibid, p. 54
} 
prisional, empreendido na busca de um exercício humanitário na prisão. Seu lema era: “os maus tratos irritam mais do que corrigem e afogam os últimos alentos da moralização”.

Tornou-se modelo para os demais países da Europa por apresentar características inusitadas e audaciosas para a época. Não admitia o regime celular, porque entendia que além de ocasionar a mortificação do apenado impedia a ressocialização face ao isolamento completo.

Adotava a autoridade moral e a missão pedagógica com vistas à correção do recluso, instituindo um "Código Interno" com regulamento para os presos, por entender que o poder de disciplina deveria estar em conformidade com o princípio da legalidade, afastandose sempre dos castigos e demais sanções disciplinares, pois estas teriam caráter infame, acreditava que o trabalho era o melhor instrumento de ressocialização do recluso, motivo pelo qual ocupava o preso com trabalho remunerado, visando despertar o seu interesse para alguma atividade produtiva.

O sistema de segurança da instituição era extremamente vulnerável, não possuindo um só ferrolho que pudesse resistir ao arrombamento de qualquer apenado e possuindo em seu quadro guardas que, em criar no recluso a idéia de que ele deveria ser coresponsável pela segurança do estabelecimento, em respeito aos seus hábitos de subordinação e moralidade.

Introduziu no sistema uma espécie de liberdade condicional, reduzindo a pena em um terço como recompensa a boa conduta do preso, estabeleceu a prática da concessão de licenças de saída temporária dos presos e não separava os reclusos pelo grau de periculosidade, pois entendia que os bons poderiam auxiliar os maus no estímulo à modificação do interior humano.

Entretanto, vinte anos após a concepção do Sistema de Montesinos, este começou a sofrer forte oposição social, o que ocasionou sua derrocada. O regime laborial do Sistema de Montesinos era tão eficiente que os fabricantes e artesãos, em virtude da competição apresentaram reclamação contra essa concorência alegando inclusive, que a mesma não estava sujeita à onerosa carga de impostos. O Governo atendeu os clamores dos empresários livres e $\operatorname{logo}$ a produção na prisão foi diminuindo, perdendo a qualidade, chegando ao ponto de não conseguir matéria-prima e sofrer forte campanha publicitária colocando em descrédito o trabalho prisional. ${ }^{33}$ 
Sem ajuda governamental e sem o apoio da sociedade, o Sistema de Montesinos foi-se afastando dos seus princípios e objetivo com a saída de Manuel Montesinos e Molina do comando do Presídio, até extinguir-se. ${ }^{34}$

\subsection{7 - O Sistema de Borstal}

A prisão de Borstal, inaugurada em 1893 para presos adultos, localizada no condado de Kent, era conhecida pelas péssimas condições em que os reclusos viviam.

Com a reforma, Borstal se transformou em uma prisão para delinqüentes entre 16 e 21 anos, bem adaptada para oferecer instrução moral e profissional aos presos.

O grande avanço do Sistema Borstal foi o pioneirismo no modelo de regime penitenciário aberto na Inglaterra. Isso começou quando, em 1930, um grupo de jovens presos se deslocou para um acampamento na cidade de Nottinghamshire e lá construiu moradia para eles e para os que viessem posteriormente. Os próprios presos concebiam a moradia como prisão. Estava assim, semeada a primeira Casa Penal Aberta, bem acolhida pela comunidade, tanto que, nos anos posteriores, o próprio Governo apoiou a fixação de outras unidades do Borstal, com o mesmo perfil para jovens delinquientes na Inglaterra. ${ }^{35}$

\subsection{Privatização dos Presídios. Surge um novo conceito}

Não apenas tem-se aumentado as críticas dirigidas contra o Sistema Penitenciário atual, como também tem conduzido a idéia de que o mesmo se encontra em crise, necessitando de um Sistema Prisional reformulado e diverso do atual.

Frente ao nosso sistema carcerário em uma situação caótica, surgem estudos e adoções de novas alternativas para a pena de prisão. Uma das mais recentes e controvertidas idéias é a de privatização.

Cabe-nos, primeiramente entender o significado de privatização. A privatização é a entrega ao particular de encargo público que o explorará economicamente, ou seja, privatizar é transferir uma empresa pública ou um órgão estatal para o setor privado ou particular, mediante uma compensação financeira, logo, a partir daí o Estado não tem

\footnotetext{
${ }^{34}$ OLIVEIRA, Edmundo . O futuro alternativo das prisões. Rio de Janeiro : Forense, 2002, cit. p. 55

${ }^{35}$ Id., Ibid., p. 55
} 
nenhuma responsabilidade para com aquele setor e seus mecanismos de cobrança são ínfimos. ${ }^{36}$

Essa tem sido uma tendência mundial. As privatizações foram iniciadas no Brasil, em 1990, pelo governo Collor, com o objetivo de modernização do Estado. As ações das empresas estatais podem ser adquiridas com dinheiro vivo ou títulos da dívida pública. ${ }^{37}$

As formas básicas de privatização quando voltada ao sistema carcerário pode ocorrer de acordo com Laurindo Dias Minhoto (2000, p 91):

“ [...] entrega da direção da prisão à companhia privada, entrega da construção à iniciativa privada que posteriormente a aluga ao Estado, utilização dos trabalhos dos presos nas prisões industriais pelos particulares e entrega de determinados serviços ao setor privado, o qual pode ser encarado também como terceirização."

Esta última tem o significado de transferir para os terceiros, determinados tipos de serviço ou trabalhos, com a finalidade primeira de diminuir custos e encargos.

Existe ainda a opção pela gestão mista que é o gerenciamento compartilhado realizado simultaneamente pelos setores públicos e privados, onde cada qual fica responsável por determinada área ou setor de comando da Casa Penitenciária.

Outros conceituam a privatização como a gestão plena por parte de empresas privadas, que desenvolvem seu trabalho a título lucrativo, em centros ou estabelecimentos tutelares ou penitenciárias, gestão que pode incluir a construção do centro ou habilitação.

A política de privatização concretizou-se com solução no controle da crise do Sistema Penitenciário em torno da década de 80, onde países como Estados Unidos da América, Inglaterra, França, Canadá e Austrália, em um contexto de explosão da população carcerária, de altos gastos e de degradação das condições de alojamento, que a idéia da privatização dos presídios surgiu como proposta, com o escopo de solucionar a crise do sistema penitenciário existente.

\footnotetext{
${ }^{36}$ OLIVEIRA, Edmundo . O futuro alternativo das prisões. Rio de Janeiro : Forense, 2002, cit. p. 60

${ }^{37}$ KOOGAN/HOUAISS. Enciclopédia e dicionário. Delta. 4ed. Rio de Janeiro. 2000.
} 
No Brasil a proposta de privatização do sistema prisional ocorreu em 1992, pelo então Presidente do Conselho de Política Criminal e Penitenciária do Ministério da Justiça, segundo Edmundo Oliveira (1992, p. 19):

“[...] a presente proposta de privatização do sistema prisional brasileiro é oriunda de reflexões sobre as modernas e recentes experiências, que nesse sentido, vêm sendo colocadas em prática em estabelecimentos prisionais dos Estados Unidos, da França, da Inglaterra, da Bélgica e da Austrália."

A questão, no entanto, é basicamente polêmica, pois inúmeros pesquisadores e especialistas no assunto posicionam-se contrários à privatização nos países onde foram adotados, verificando a possibilidade de importação dos modelos estrangeiros para o Brasil. 


\section{CAPÍtULO II}

\section{MODELOS DE PRIVATIZAÇÃO DO SISTEMA PENITENCIÁRIO NO MUNDO}

\subsection{Modelo Norte-Americano de Prisão Privada}

Em 1985 eram ensaiadas nos Estados Unidos da América as primeiras iniciativas com prisões privadas, tendo como causas principais, as sérias crises estruturais pelos quais o sistema penitenciário norte-americano vinha passando, especialmente a superpopulação carcerária que já alcançava aproximadamente $115 \% .{ }^{38}$

Este estrondoso aumento da população prisional sem um correspondente aumento de vagas nas prisões deu ensejo a uma crescente intervenção judicial sobre a atuação dos departamentos de administração prisional, para que estes expandissem sua capacidade de alojamento ou reduzissem o número de detentos. Em 1987, 60\% dos Estados Unidos da América se encontravam sob ordem judicial para reduzir a lotação de suas casas prisionais. ${ }^{39}$

Nos Estados Unidos da América há três níveis de administração da Justiça Penal: a Administração Federal, a Administração Estadual e a Administração dos Condados.

A Administração da Justiça Federal ocupa-se dos presos que cometeram infrações às leis federais, podendo também receber infratores às leis dos Estados, especialmente nos casos de crimes que prevêem penas longas.A Administração da Justiça Estadual abriga os presos por infrações menos graves, que em geral não ultrapassam dois anos de prisão.Na Administração da Justiça dos Condados ou dos Municípios, os presos que aguardam julgamento ou já foram condenados a mais de um ano de prisão são sempre transferidos para uma prisão de Estado. ${ }^{40}$

Experimentos com a participação da iniciativa privada no Sistema Penitenciário Norte-americano foram a princípio levados a efeito nas chamadas Prisões de

\footnotetext{
${ }^{38}$ OLIVEIRA, Edmundo . O futuro alternativo das prisões. Rio de Janeiro : Forense, 2002, cit. p. 322

${ }^{39}$ MINHOTO, Laurindo Dias. Privatização de Presídios e Criminalidade. São Paulo: Max Limonad, 2000, cit. p.53.

${ }^{40}$ Id. Ibid, p. 344
} 
Xerifes, existentes nos Condados dos Estados Unidos para acolher pessoas presas provisoriamente ou por períodos curtos, após cometerem pequenas infrações. ${ }^{41}$

No início, a Secretaria Federal das Prisões dos Estados Unidos estava pouco inclinada a aceitar empresas privadas no gerenciamento de prisões fechadas de segurança máxima, admitindo somente a participação de empresas em casos de prisões para jovens ou em casos de prisões femininas, como vinha acontecendo nos Condados, mas no Relatório de 1988, a Comissão Presidencial de Privatizações recomendou também a experiência de confiar a uma empresa privada o comando de uma Prisão Federal de Segurança Máxima.

A Secretaria Federal de Prisões passou, então a realizar Contratos que permitiam recorrer aos conhecimentos e aos recursos do setor privado para a concepção, a construção e o financiamento das novas prisões, dentro de um planejamento que ensejasse a construção de novos estabelecimentos em menos tempo e a menor custo. Em 1991, cerca de 415 Contratos já haviam sido assinados para a construção de estabelecimentos, tanto para penas longas, como para penas médias ou curtas, os quais atingiram a média de 16.000 novas vagas em todo o país.

A primeira experiência em larga escala se deu no Texas, em 1987, onde o Departamento de Justiça Criminal do estado contratou duas empresas a Corrections Corporation of America - CCA e Wackenhut, para operarem, cada uma, duas prisões com capacidade para 500 detentos. Todos os quatro contratos contavam com rígidos requisitos de qualidade, superiores aos impostos às prisões administradas pelo Estado. ${ }^{42}$

Os contratos realizados pelo Estado prevendo a participação da iniciativa privada no sistema penitenciário norte-americano, em regra são pactuados em longos prazos de duração de 10 a 30 anos, visando possibilitar o desenvolvimento de atividade econômica que propicie não só o trabalho ao condenado, mas também retorno do investimento.

De acordo com um relatório de 2003, pesquisas mostraram que as prisões privatizadas poupam dinheiro, bem como exercem pressão sobre o sistema penitenciário público, restringindo a elevação dos custos. ${ }^{43}$

Com menos de 5\% de suas populações carcerárias em instalações privatizadas experimentaram um aumento de $12,5 \%$ nos gastos, já nos estados sem prisões privatizadas obtiveram um aumento de $18,9 \%$. Estados com maior porcentagem para a gestão privada

\footnotetext{
${ }^{41}$ OLIVEIRA, Edmundo . O futuro alternativo das prisões. Rio de Janeiro : Forense, 2002, cit. p. 345

${ }^{42}$ THOMAS, Charles W. in TABARROK, Alexander (org.). Changing the Guard. Oakland: The Independent Institute, 2003, p. 116.

43 <http://en.wikipedia.org/wiki/Corrections_Corporation_of_America> . Acesso em 19/07/2013.
} 
tiveram maior poupança mesmo com o crescimento dos gastos em apenas 5,9\% durante o período estudado. ${ }^{44}$

Em um estudo de 2008, indicou que os estados podem economizar uma quantidade substancial de dinheiro, se eles utilizam o sistema de "Gestão Compartilhada" (parceria público/privada). A pesquisa revelou que, durante o período de estudo (1999-2004), os estados economizavam até U\$ 15 milhões em seu orçamento anual. O estudo foi supervisionado por James Blumstein, diretor do Centro de Política de Saúde, Vanderbilt Institute for Public Policy Studies. ${ }^{45}$

Os que posicionam à favor da privatização das penitenciárias argumentam que o cárcere privado é uma das soluções mais baratas para o Estado e consequentemente para a sociedade, julgando com base nas experiências que estão em curso há vinte anos nos estados. ${ }^{46}$ Ao comparar com as penitenciárias do setor público analisa-se que há poucas tentativas de fuga, praticamente não há suicídios, há menos casos de reicidência e, portanto considera-se que a reitegração social é mais bem sucedida através de programas de reabilitação, ocorre a redução dos custos unitários e os conflitos internos são resolvidos através de contratos de seguro.

A partir de 2009, cerca de 5\% de todos os delinquentes nos Estados Unidos encontram-se alojados em instalações de gestão privada. Alguns Relatórios independentes projetam um aumento constante. ${ }^{47}$

Portanto, em decorrência do sistema prisional tripartido, nos Estados Unidos existem três formas de participação da iniciativa privada no Sistema Penitenciário.

A primeira delas é a denominada "Gestão Privada Total", a empresa constrói o estabelecimento e é proprietária da prisão, sendo responsável pelo gerenciamento completo, cabendo ao Estado apenas a fiscalização diária para acompanhar a administração e ficar vigilante quanto a preservação da dignidade e dos direitos humanos no tratamento penitenciário.

A segunda forma utilizada é a denominada "Gestão Privada Compartilhada", o Estado cede o estabelecimento arquitetônico para a empresa privada administrar a prisão. A administração superior do estabelecimento pode ficar a cargo do Estado.

\footnotetext{
44 SEGAL, Geoffrey F.Increased Competition in Department of Corrections Will Lead to Additional Savings .Virginia Viewpoint, 2003.

${ }^{45}$ CCA Provider correções nomeado para a revista Empregos Top List 50 GI Militar de empregadores Friendly

${ }^{46}$ THOMAS, Charles W. in TABARROK, Alexander (org.). Changing the Guard. Oakland: The Independent Institute, 2003, p. 116

$47<$ http://en.wikipedia.org/wiki/Corrections_Corporation_of_America> Acesso em19/07/2013.
} 
A terceira modalidade adotada nos Estados Unidos é a "Gestão Privada Compartilhada para a fase final da pena"48, onde após submeter-se a dois terços em uma Prisão Pública, o condenado tem a opção de cumprir o restante da pena em uma prisão privada.

\subsection{Modelo Inglês de prisão privada}

A privatização de penitenciárias surgiu como proposta efetiva em 1984, prevendo a participação da iniciativa privada na construção e administração de estabelecimentos penais para presos provisórios. ${ }^{49}$

O desenvolvimento da privatização na Grã-Bretanha está muito ligado com a experiência americana. A maior semelhança incide no tipo de problemas que os respectivos sistemas penais enfrentaram. Em ambos, as taxas de criminalidade vinham aumentando, principalmente a reincidência, acarretando um excesso de população carcerária. Em 1987, a população prisional da Inglaterra e do País de Gales, de aproximadamente 50.000 detentos era a segunda maior da Europa Ocidental, só perdendo para a Turquia. ${ }^{50}$

Além de superlotadas, a administração das prisões tem encarecido substancialmente. O gasto do Estado no Sistema Penitenciário subiu, entre 1976 e 1986, de 163 milhões para 786 milhões de libras, e entre 1988 e 1996, de 1,029 bilhões para 1,5 bilhões de libras. ${ }^{51}$

Contudo há muitas diferenças nos respectivos sistemas penais e na Administração e Finanças públicas.

O sistema britânico é mais centralizador do que o americano, com uma transferência muito maior de poderes para o Governo Federal. Já o sistema penitenciário norte-americano é estruturado entre os diversos estados e uma enorme quantidade de municípios, o que resulta numa pluralidade de sistema dentro de um único país. ${ }^{52}$

Com a elaboração do "The Criminal Justice Act 1991", 53 formalizou-se o instrumento legal que inicia o processo de privatização do sistema penal na Grã-Bretanha, que começou com a construção dos estabelecimentos para presos provisórios. Tal diploma legal estabelece as atribuições dos empresários e do Governo, a forma da futura organização

\footnotetext{
${ }^{48}$ OLIVEIRA, Edmundo . O futuro alternativo das prisões. Rio de Janeiro : Forense, 2002, cit. p. 325.

${ }^{49}$ Id. Ibid. p. 327.

${ }^{50}$ RUSSEL, C.K. Privatizatio of prisions - "New Law Journal. Apid”. MINHOTO, Laurindo Dias. Op. cit., p. 58.

${ }^{51}$ Id. Ibid. p.58

${ }^{52}$ RUSSEL, C. K. op. cit, p. 58.

${ }^{53}$ MACHADO, Ricardo. Privatização (gestão privada) ou co-gestão do Sistema Penitenciário Brasileiro?. Instituto Teotônio Vilela, Brasília, DF, 2000, p. 14.
} 
administrativa, à maneira de prestação de contas, de controle, os direitos dos presos, enfim, há a sistematização de uma nova estrutura penitenciária.

A tendência é a de incrementar o programa de privatização para abranger as demais áreas do sistema penitenciário, de acordo com o conceito mais amplo de privatização que abrange serviços, alimentação e direção do estabelecimento. ${ }^{54}$

Portanto, contrariamente aos rumos que o processo de privatização vem tomando nos Estados Unidos da América, onde há uma diretriz que limita o conceito de privatização à contratação de serviços e aquisição de bens com empresa privada, na GrãBretanha a diretriz principal da política penitenciária segue o rumo à tendência de privatização total do sistema. Entretanto, tal direcionamento ainda será objeto de uma discussão jurídica na Grã-Bretanha, ao contrário dos Estados Unidos, é possível questionar-se a constitucionalidade da transferência a particulares do poder punitivo da responsabilidade pela guarda dos presos..$^{55}$

\subsection{Modelo Francês de "prisão privada".}

A idéia de participação da iniciativa privada no sistema penitenciário francês tomou grandeza no início da década de $80^{56}$ e assim, como em todos os países do mundo em que algumas de suas modalidades foram adotadas, surgiu em decorrência de uma crise penitenciária, ocasionada especialmente pela superpopulação carcerária, sem se falar nas péssimas condições estruturais dos estabelecimentos penais existentes à época.

Os precedentes da idéia de privatização vieram em especial dos Estados Unidos, com o crescimento a partir de 1985 dos estabelecimentos privados na Flórida, Califórnia e etc. ${ }^{57}$

Diante da situação calamitosa do Sistema Prisional Francês, em 1986, foi apresentado à Assembléia Nacional um plano amplo e ambicioso de construção de penitenciárias visando abrigar o excedente carcerário (déficit de 12.000 a 17.000 vagas) e proporcionar novas vagas para a população carcerária prevista para os anos seguintes (de 30.000 a 40.000 vagas). Foi o chamado "Projeto 15.000", cuja finalidade era a criação urgente

\footnotetext{
54 MACHADO, Ricardo. Privatização (gestão privada) ou co-gestão do Sistema Penitenciário Brasileiro?. Instituto Teotônio Vilela, Brasília, DF, 2000, p. 15.

${ }_{56}^{55}$ Id. Ibid. p. 15

${ }^{56}$ OLIVEIRA, Edmundo . O futuro alternativo das prisões. Rio de Janeiro : Forense, 2002, cit. p. 325

${ }^{57}$ Id. Ibid.. p. 325
} 
e imediata de 15.000 vagas, o que aconteceria mediante a entrega total - como forma de reduzir custos e investimentos no setor - de todo o planejamento, preparação e construção de 25 novas prisões espalhadas em várias regiões da França à iniciativa privada (modelo de privatização total). ${ }^{58}$

Desde seu aparecimento, o projeto causou enorme polêmica junto à opinião pública francesa, ensejando calorosos debates no Parlamento. Como havia de se esperar, logo surgiram dois grupos antagônicos (defensores e opositores), os quais passaram a emitir posicionamentos sobre o tema. ${ }^{59}$

Uns defendiam a idéia principal desse sistema, a introdução da iniciativa privada para a construção e manutenção das prisões, pelo fato de que o Estado não possuía dotação orçamentária suficiente para custeá-lo. ${ }^{60}$ De outro lado, os opositores, dentre eles o Presidente François Mitterand, defendiam que a administração pública prisional é indelegávelmente função jurisdicional do Estado, já que o encarceramento é indissociável do poder de julgar e sancionar. O presidente francês preocupou-se também com o fato de que, o objetivo de lucro pelas empresas privatizadas geraria um sério risco à gestão privada das prisões. ${ }^{61}$

Os debates legislativos não acolheram in totum o Projeto 15.000, a idéia de privatização total não foi levada adiante. A questão terminou com a promulgação da Lei 87.432 de 22/06/1987, a qual autorizou a participação da iniciativa privada no sistema penitenciário francês, na forma de co-gestão (e não gestão privada conforme intenção do Projeto 15.000), primeiramente na edificação de prisões e posteriormente, na execução de certas atividades, tal como a organização do trabalho, da educação, do lazer, da alimentação, do fornecimento de vestimentas, da guarda e demais serviços relacionados com o preso, oferecendo assistência médica, social, jurídica, inclusive a segurança interna da instituição prisional (agentes carcerários). A parceria, portanto, se tornará celebrada após o processo licitatório, através de uma convenção aprovada por Decreto. ${ }^{62}$

Conforme o exposto na Lei 87.432, de 22/06/87, ao Estado incube a indicação do Diretor Geral do estabelecimento, seu relacionamento com o juízo da execução penal e das Instituições Penitenciárias (função da polícia do Estado). Os estabelecimentos públicos penitenciários serão administrados por um Conselho de Administração, composto por

\footnotetext{
${ }^{58}$ OLIVEIRA, Edmundo . O futuro alternativo das prisões. Rio de Janeiro : Forense, 2002, cit. p. 325

${ }^{59}$ MACHADO, Ricardo. Privatização (gestão privada) ou co-gestão do Sistema Penitenciário Brasileiro?. Instituto Teotônio Vilela, Brasília, DF, 2000, p. 12.

${ }^{60}$ Id. Ibid. p. 12.

${ }^{61}$ MACHADO, Ricardo. Op. Cit. p. 12

${ }^{62}$ MACHADO, Ricardo. Op. Cit. p. 12
} 
representantes do Estado majoritários, das assembléias locais, do pessoal, assim como de pessoas jurídicas, associações e personalidades escolhidas em razão de sua competência no campo da execução das penas e da reinserção social. Cabe ao Ministro da Justiça a designação do Presidente do Conselho de Administração dentre os representantes do Estado.

Em 1988 foi aprovado o Projeto intitulado "Programme 13.000", ${ }^{63}$ pelo qual o governo com a participação do capital da iniciativa privada, deveria construir 13.000 celas, distribuídas por 25 penitenciárias espalhadas em várias regiões da França. Feita a concorrência pública, quatro grupos de empresas francesas comprometeram-se a construir penitenciárias e compartilhar com o Estado o compromisso da administração dos estabelecimentos vinculados ao "Programme 13.000".

Neste sistema de participação da iniciativa privada (denominado sistema misto), regulamentado por Contrato de Gestão renovável de duração de 10 anos, as empresas cujas atividades foram delegadas recebem do Estado uma quantia por preso/dia, pela prestação dos serviços acima mencionados e autorizados pela Lei 87.432 de 22/06/1987. ${ }^{64}$

No âmbito deste regime inovador, foi construída em 1990, a prisão de Osny, e deste então torna-se importante ressaltar que a participação da iniciativa privada no sistema prisional francês passou e continua a passar por um forte esquema, observação e fiscalização, pelo Departamento de Assuntos penitenciários do Ministério da Justiça francês com o objetivo de apurar a sua validade.

${ }^{63}$ OLIVEIRA, Edmundo. Op. cit. p. 329

${ }^{64}$ OLIVEIRA, Edmundo. Op. cit. p. 329 


\section{CAPÍTULO III}

\section{A PRIVATIZAÇÃO DO SISTEMA PENITENCIÁRIO BRASILEIRO}

\subsection{Argumentos Contrários a "Privatização"}

No Brasil, à idéia de privatização dos presídios ocasionou alguns argumentos contrários de três ordens: argumentos éticos, jurídicos e políticos. Vejamos cada um deles.

\subsubsection{Argumentos éticos}

Para àqueles contrários a participação da iniciativa privada no sistema penitenciário, a garantia constitucional do direito à liberdade, prevista no art. $5^{\circ}$, caput da Constituição Federal de 1988, reconhece no âmbito da ordem jurídica, o comando ético segundo o qual não será moralmente válido a um homem exercer sobre o outro qualquer espécie de poder, que se manifeste pela força. A única coação moralmente válida é a exercida pelo Estado através da imposição e execução de penas e outras sanções previstas em lei.

Destarte, seja do ponto de vista moral ou jurídico, o Estado não está legitimado a transferir a uma pessoa, natural ou jurídica, o poder de coação de que está investido e que é exclusivamente seu, por ser, tal poder, violador do direito de liberdade. Neste ponto, o aspecto ético se confunde com o aspecto jurídico constitucional e fundamenta a inconstitucionalidade da proposta de privatização. ${ }^{65}$

O eminente professor Júlio Fabbrini Mirabete opina que:

\footnotetext{
"Somente o Estado, na sua função de promover o bem comum e combater a criminalidade, tem o direito de estabelecer $e$
}

65 MACHADO, Ricardo. Privatização (gestão privada) ou co-gestão do Sistema Penitenciário Brasileiro?. Instituto Teotônio Vilela, Brasília, DF, 2000, p. 7. 
aplicar essas sanções. É, pois, o único e exclusivo titular do 'direito de punir' (jus puniendi) que constitui o que se denomina Direito Penal subjetivo" ${ }^{66}$

Entretanto há mais: alegam os opositores da proposta privatizante ser também inconcebível que um indivíduo, além de exercer domínio físico sobre o outro, aufira vantagem econômica, do trabalho carcerário. Entendem eles, que o trabalho carcerário faz parte da natureza da pena, que é, como acabamos de ver, manifestação do poder soberano do Estado. ${ }^{67}$ Portanto, somente ao Estado será moralmente lícito obter receita desse trabalho.

Ademais, alegam que a preocupação maior da iniciativa privada, no setor penitenciário, seria exclusivamente o lucro, decorrendo daí o risco da utilização do trabalho escravo (ausência da livre adesão do preso) pela iniciativa privada, sem garantia de reinserção social do delinqüente. ${ }^{68}$

Ainda com relação ao aspecto ético, destacam que a privatização corre um grande risco de cair nas mãos de empresas particulares controladas por segmentos do crime organizado. Acentuam ainda os críticos que a iniciativa privada não tem nenhum interesse em diminuir a superpopulação carcerária, nem de melhorar a qualidade de vida nas prisões, visto que receberão por preso, e o contrato em base per capita garante a margem de lucro oriundo da própria existência da criminalidade. ${ }^{69}$

Por fim, os adversários da privatização enfatizam que, com o pensamento fixo no proveito financeiro, os grupos particulares, sem experiência com assuntos de pedagogia penitenciária, não terão o cuidado de contratar pessoal qualificado e bem treinado, uma vez que é mais vantajoso pagar menos, ainda que o servidor não tenha preparo cientifico para o trabalho que vai desempenhar na prisão. Por outro lado, fugindo dos riscos, mais despesas e problemas maiores, as empresas privadas só vão querer os presos bem comportados, não violentos e sem antecedentes não recomendáveis, deixando a sobrecarga das dificuldades para o Estado, que sempre terá que se ocupar com presos perigosos e de difícil recuperação. ${ }^{70}$

\subsubsection{Argumentos jurídicos}

\footnotetext{
${ }^{66}$ MIRABETE, Julio Fabbrini. Execução Penal, 5a Ed. Editora Atlas, São Paulo, 1995 p. 28. Op. cit., p. 115.

${ }^{67}$ VASCONCELOS, Arnaldo. Direito, Humanismo e Democracia. Malheiros, São Paulo-SP, 1998, p.35.

${ }^{68}$ OTTOBONI, Mário. A questão da Privatização das Prisões. Paulinas São Paulo-SP, 1992 p. 41.

${ }^{69}$ MINHOTO, José Laurindo. Privatização de presídios e criminalidade: A gestão da violência no capitalismo. São Paulo, Max Limonad, 2000, p. 25.

${ }^{70}$ Id. Ibid. p. 27.
} 
Os opositores à idéia privatizante apresentam ainda obstáculos de ordem constitucional e legal, os quais passaremos a ver.

Conforme já anteriormente mencionado, as críticas constitucionais confundemse com os obstáculos éticos apresentados. Alegam os opositores que o ideal privatizante conflita com os direitos e garantias fundamentais assegurados na Constituição Federal de 1988.

Aduz a doutrina contrária que ao prescrever a Carta Magna em seu art. 5o, inciso III que "ninguém será submetido a tortura nem a tratamento desumano ou degradante” encontra-se intrínseco que somente o Estado está investido do poder de coação, sendo portanto indelegável tal poder a outra pessoa, seja física ou jurídica, caracterizando inconstitucional qualquer proposta privatizante. ${ }^{71}$

Não obstante, a doutrina defende ainda que há também violação ao artigo $5^{\circ}$, LII da Constituição Federal, que estabelece que "ninguém será processado nem sentenciado senão pela autoridade competente”. Para a doutrina contrária à participação da iniciativa privada no Sistema Prisional, a execução da pena é decorrência material do julgamento pela autoridade judicial, portanto, continuação da atividade jurisdicional, o que nada mais é do que a função que o Estado tem de dirimir conflitos. ${ }^{72}$

Desse raciocínio, extrai-se o entendimento de que a atividade executiva penal é uma função pública, por ser continuação de uma função do Estado (prestação jurisdicional), e não apenas um serviço público como defendem os favoráveis a participação da iniciativa privada. E assim sendo, estaria impedida qualquer tipo de participação da iniciativa privada na execução da pena, visto que a função do Estado é constitucionalidade indelegável. ${ }^{73} \mathrm{~A}$ empresa privada não seria autoridade, na forma do texto constitucional, logo, não poderia ser encarregada da execução penal, da fiscalização do cumprimento da pena imposta pelo Poder Judiciário. Defendem aqueles que trata-se de atividade típica do Estado, indelegável ao particular. Somente o Estado poderia exercer essa função de forma direta, através de seus órgãos ${ }^{74}$.

Ademais, segundo a doutrina contrária, ainda que se entenda que a execução penal constitui um serviço público, e não uma função do Estado, tanto os contratos de cessão

\footnotetext{
${ }^{71}$ MIRABETE, Julio Fabbrini. Execução Penal, 5a Ed. Editora Atlas, São Paulo, 1995 p. 28.

${ }^{72}$ CAPEZ, Fernando. Curso de Processo Penal. 17a ed. Saraiva, São Paulo 2010 pg. 15.

${ }^{73}$ NUCCI, Guilherme de Souza. Manual de Processo Penal e Execução Penal. 6a. ed. vol.1 São Paulo: Revista dos Tribunais, 2010. p.29.

${ }^{74}$ MINHOTO, José Laurindo. Privatização de presídios e criminalidade: A gestão da violência no capitalismo. São Paulo, Max Limonad, 2000, p. 58.
} 
de obra como os de serviço público (Contratos Administrativos) objetivam um negócio jurídico, que permite que o particular cobre taxas e tarifas dos usuários, o que as torna inadequada à privatização de prisões, visto que o preso não pode ser considerado um usuário. $^{75}$ Tal pessoa goza da liberdade que lhe permite optar ou não em fazer uso dos bens e serviços que está a sua disposição, podendo ser sujeito passivo da incidência de taxas e tarifas. O preso, por sua vez, não está na prisão por vontade própria, mas por imposição do Estado, não possuindo liberdade de escolha e portanto não sendo usuário não pode haver cobrança de qualquer taxa ou tarifa pela empresa privada. ${ }^{76}$

Quanto a alegação de que a empresa privada auferirá lucros do trabalho dos reeducandos, contestam os contrários afirmando que essa forma de pagamento nada tem a ver com as que estão previstas na Lei de Licitações e Contratos hoje em vigor. ${ }^{77}$

Por fim, defendem que a administração das penitenciarias é uma questão de segurança pública, e esta, nos termos do art. 144 da CF/88 é dever do Estado e será exercida pelos órgãos constitucionalmente incumbidos desse dever, entre os quais não se encontra a iniciativa privada, senão vejamos:

\footnotetext{
"Art. 144 - A segurança pública, dever do Estado, direito e responsabilidade de todos, é exercida para a preservação da ordem pública e da incolumidade das pessoas e do patrimônio, através dos seguintes órgãos:

I- Polícia Federal;

II- Polícia Rodoviária Federal;

III- Polícia Ferroviária Federal;

IV- Polícias Civis;

V- Polícias Militares e Corpos de Bombeiros Militares $(\ldots)^{78}$
}

\subsubsection{Argumentos Políticos}

\footnotetext{
${ }^{75}$ MOTTA, Carlos Pinto Coelho. Eficácia nas Licitações e Contratos. 11 $1^{\text {a }}$ Ed. Del Rey, Belo Horizonte, 2010 p. 87.

${ }^{76}$ MINHOTO, José Laurindo. Privatização de presídios e criminalidade: A gestão da violência no capitalismo. São Paulo, Max Limonad, 2000, p. 64.

${ }^{77}$ RIBEIRO, Armando Lúcio. Privatização (Terceirização) dos Presídios. Disponível em <http://www.mp.rn.gov.br/artigo/caops/caopjp/teses/privatizacao_presidios.pdf>. Acesso em 10 de agosto de 2013.

${ }^{78}$ BRASIL. Constituição da República Federativa do Brasil.
} 
Em termos políticos, a inserção do setor privado na relação prisional tem acalentado dúvidas quanto à compatibilidade entre a função pública no processo de tomada de decisões, inerente à formulação da política criminal e a finalidade lucrativa das empresas. Minhoto doutrina que há receio que "os interesses privados das companhias passem a influir crescentemente na definição dos termos e na condução criminal"79

A política de adoção de penitenciárias privatizadas, tem significado na prática um reforço da prisão como "locus" privilegiado das estratégias de controle penal e, mais do que isso, pode abrir caminho para a criação de um poderoso "lobby", extremamente interessado no aumento da população penitenciária. ${ }^{80}$

Sobre o mesmo sentido alguns estudiosos analisaram que altas taxas de reincidência podem vir a se constituir subproduto das prisões privadas. ${ }^{81}$

Segundo Elizebeth Sussekind, ao se fazer uma modesta reflexão já se chega à conclusão da impropriedade política do modelo de gerenciamento privado de prisões:

\footnotetext{
“o objetivo teórico da administração penitenciária é combater a criminalidade e não obter lucros; ora, as empresas que desejam participar da administração penitenciária visam obter lucros e retiram esse lucro da própria existência da criminalidade; logo, tais empresas que têm interesse em manter seus lucros não irão lutar contra a criminalidade; e se não têm tal interesse não devem administrar prisões", 82
}

Por fim, para os críticos fica evidente que as empresas administradoras não estão nunca dispostas a encarregar-se de determinados tipos de presos que por suas características violentas, conflitivas ou de precária saúde resultem excessivamente caro. Com isso acabaria por se ter prisões privadas esplêndidas, para reclusos não conflitivos ou sãos, e prisões com amontoamentos e insalubres para reclusos rebeldes. ${ }^{83}$

\footnotetext{
${ }^{79}$ MINHOTO, Laurindo Dias. Privatização de Presídios e Criminalidade: a gestão da violência no capitalismo global. São Paulo: Max Limonad, 2000 p. 89

80 BERG, Julie. Private prisons: International experiences and South African prospects. Disponível em <http://web.uct.ac.za/depts/sjrp/publicat/pripris.pdf. >Acesso em 13 de maio de 2013.

${ }^{81}$ SILVA, Cosmo Sobral da; BEZERRA, Everaldo Batista. A terceirização de presídios a partir do estudo de uma penitenciária do Ceará. Jus Navigandi, Teresina, ano 10, n. 645, 14 abr. 2005. Disponível em: <http://jus.uol.com.br/revista/texto/6541>. Acesso em: 15 de setembro de 2013.

${ }^{82}$ SUSSEKIND, Elizebeth. Aspectos da política prisional no Brasil. Revista CEJ. Ano 5, no 15. Brasília, dez 2001, p.25-30.

${ }^{83}$ MINHOTO, Laurindo Dias, op cit., p. 92.
} 


\subsection{Argumentos Favoráveis a "Privatização"}

Em contrapartida, a doutrina favorável à participação da iniciativa privada no Sistema Prisional Brasileiro arrola argumentos de inúmeras e diversificadas naturezas, as quais pode-se dividir em argumentos éticos, políticos e jurídicos, visando assim uma verificação com maior clareza sobre os prós e contras do modelo privatizante.

\subsubsection{Argumentos éticos}

Os partidários da privatização mostram que o Estado, há muito tempo, não investe devidamente no sistema penitenciário. Assim sendo, dizer não à privatização, precipitadamente, é concordar com o caos instalado em prisões que são verdadeiras unidades do crime, constituindo um sistema irresponsável, antiético, desumano, caótico. Sublinham os defensores da privatização que as empresas particulares dispõem de maior agilidade, uma vez que estão liberadas a morosa e difícil burocracia, que dia a dia prejudica a lenta rotina das instituições estatais. A par dessa peculiaridade, sustentam que os grupos particulares procuram sempre oferecer estímulos funcionais e melhores condições a seus empregados e na competição de mercado, além de garantirem trabalho remunerado ao preso - o que não ocorre comumente na prisão estatal - eles têm agudo interesse em otimizar os serviços, reduzindo as despesas para manter a posição estável e não sofrer as penalidades que deverão constar contratualmente, preocupações essas que não são relevantes no serviço público, que gasta demasiadamente, está sempre envolto em escândalos de corrupção e vem fracassando através dos tempos, como detentor do monopólio da execução penal. ${ }^{84}$

No que tange a possibilidade do trabalho escravo nas dependências das unidades prisionais que possua participação da iniciativa privada, a doutrina favorável argumenta não haver qualquer fundamento no modelo proposto no Brasil, pois a privatização propiciaria oportunidade para que o preso pudesse trabalhar em sintonia com suas expectativas e com o comando emanado da lei. ${ }^{85}$ Salienta-se que proporcionar trabalho não significa explorar a mão de obra do preso, pois o preso podendo trabalhar, receberá a remuneração estabelecida por lei pelo seu esforço, paga pelo tomador do serviço, e o dinheiro recebido deverá atender o disposto na Lei de Execuções Penais, visando reparar prejuízos

\footnotetext{
${ }^{84}$ MACHADO, Ricardo. Privatização (gestão privada) ou co-gestão do Sistema Penitenciário Brasileiro?. Instituto Teotônio Vilela, Brasília, DF, 2000, p. 7.

${ }^{85}$ SILVA, Cosmo Sobral da; BEZERRA, Everaldo Batista. A terceirização de presídios a partir do estudo de uma penitenciária do Ceará. Jus Navigandi, Teresina, ano 10, n. 645, 14 abr. 2005. Disponível em: 〈http://jus.uol.com.br/revista/texto/6541>. Acesso em: 15 de setembro de 2013.
} 
causados à vítima com sua conduta criminosa, destinando-se ainda, parte do recurso para a família do preso, que geralmente encontra-se desamparada desde a reclusão do "chefe de família”, além de reservar parcela do recurso para um pecúlio destinado ao próprio preso quando lhe for atribuída a liberdade. ${ }^{86}$

Assim, o preso poderá trabalhar e receberá por seu trabalho, dinheiro que se destinará a ele e sua família, mas jamais para o empreendedor privado. A iniciativa privada receberá do Estado, jamais do preso, motivo pelo qual toma-se totalmente absurda a alegação sobre possível utilização de trabalho escravo nas dependências de unidades prisionais que disponham da participação da iniciativa privada em sua administração, até porque quem determina quando e por quanto tempo o homem deve permanecer preso é o Estado-juiz, portanto, o empreendedor não tem nenhuma ingerência no trabalho do preso, a não ser em propiciar condições de trabalho. ${ }^{87}$

Importante também ressaltar sobre o fato de que, na penitenciária privada, o trabalho produtivo do preso, gerando recursos em benefício do próprio sistema, vai possibilitar que as verbas, hoje destinadas para a construção de penitenciárias e manutenção dos presos, no falido sistema penitenciário estatal, sejam voltadas para a área da política educacional, que muito tem a fazer para prevenir a delinquência. ${ }^{88}$

Ademais, quanto ao argumento da doutrina contrária de que não será moralmente válido a um homem exercer sobre o outro qualquer espécie de poder, que se manifeste pela força, os favoráveis ao modelo privatizante alegam que o exercício do poder de segregação é e continuará sendo do Estado, visto que apenas a atividade administrativa extrajudicial contaria com a participação da iniciativa privada. ${ }^{89}$

A demonstração de que o poder continua do Estado é que este poderá, em havendo qualquer irregularidade da empresa contratada, rescindir ou aplicar as penalidades previstas contratualmente, possuindo, inclusive, agentes públicos no interior da instituição penitenciária para acompanhamento e fiscalização da administração privada..$^{90}$

No que tange a argumentação de que a empresa administradora da instituição prisional não conterá a superpopulação, esta não prospera, visto que, para a doutrina favorável ao projeto privatizante, a capacidade da instituição prisional estará prevista contratualmente.

\footnotetext{
${ }^{86}$ NUCCI, Guilherme de Souza. Manual de Processo Penal e Execução Penal. 6a. ed. vol.1 São Paulo: Revista dos Tribunais, 2010. p.38.

${ }^{87}$ MINHOTO, Laurindo Dias. Privatização de Presídios e Criminalidade: a gestão da violência no capitalismo global. São Paulo: Max Limonad, 2000 p. 101.

${ }^{88}$ D`URSO, Luiz Flávio Borges. A privatização de presídios: uma breve reflexão. Disponível em:

< http://www.eknippel.adv.br/default.asp?ACT=s\&content=43\&id=32\&mnu=32> Acesso em 10 de julho de 2013.

${ }^{89}$ DI PIETRO, Maria Sylvia Zanella. Parcerias na administração pública. São Paulo: Atlas, 2002. p. 47

${ }^{90}$ Id. Ibid. p. 47
} 
Ademais, a destinação de novos reeducandos à instituições prisionais compete ao Estado, e não a iniciativa privada, a qual apenas recepciona-os e administra a instituição. Caso haja superpopulação, esta é e continuará a ser de responsabilidade exclusiva do Estado que não consegue manter equiparação ente o número de vagas no sistema prisional e a demanda de novos presidiários. ${ }^{91}$

Não obstante, quanto a argumentação de que a empresa privada, não terá interesse em contratar pessoal habilitado por custar mais caro, significa subestimar o interesse comercial do negócio, pois, sendo negócio, não deve ser visto como uma aventura efêmera, o que causaria prejuízo ao investidos, há que se saber que o empreendedor privado só tem um caminho, o do investimento, o da competitividade, sob pena de perder o contrato e sair do negócio, sendo portanto, sua obrigação otimizar os recursos para aliciar os melhores profissionais da área. ${ }^{92}$

A diferença econômica entre a administração estatal e a privada pode ser facilmente explicada. Um dos meios aos quais recorrem as empresas privadas para melhorar o rendimento e diminuir o custo consiste em recrutar pessoas desejosas de trabalhar nesse sentido, que serão recompensadas pelas economias e melhorias que trazem. Não é exagero dizer que os funcionários públicos estão menos dispostos a inovar, porque, em geral, não são recompensados por suas iniciativas. A rotina, a espera, a promoção por antiguidade e um certo distanciamento frente ao trabalho constituem características dos funcionários públicos vinculados aos serviços penitenciários de todo o mundo e, em especial no Brasil. ${ }^{93}$

Quanto a eficácia do serviço privado, em matéria de economia e pessoal, ela é incontestável. Quase todos os agentes penitenciários são funcionários que têm direito a uma pensão, a uma carreira, a aumentos regulares, a uma promoção, a vantagens de função, a licença por doenças, às prestações de saúde e a seguros. Em contrapartida, os empregadores privados são obrigados a respeitar as leis e os regulamentos sobre o emprego, mas têm uma certa margem de manobra para evitar as despesas excessivas de pessoal e fixar salários em conformidade com a evolução do mercado de trabalho. Eles têm também mais facilidade para empregar pessoal com tempo parcial, temporário ou complementar de um outro emprego. Podem, ainda, para um determinado cargo, empregar pessoas menos qualificadas no plano intelectual, educativo, físico, o que normalmente não é possível na função pública. ${ }^{94}$

\footnotetext{
${ }^{91}$ OLIVEIRA, Edmundo . O futuro alternativo das prisões. Rio de Janeiro : Forense, 2002, cit. p. 302.

92 DURSO, Luiz Flávio Borges. A privatização de presídios: uma breve reflexão. Disponível em: < http://www.eknippel.adv.br/default.asp?ACT=s\&content=43\&id=32\&mnu=32> Acesso em 10 de julho de 2010.

93 OLIVEIRA, Edmundo. Op. cit., p. 312.

${ }^{94}$ MINHOTO, Laurindo Dias. Privatização de Presídios e Criminalidade: a gestão da violência no capitalismo global. São Paulo: Max Limonad, 2000 p. 117.
} 


\subsubsection{Argumentos jurídicos}

Defende a doutrina, favorável às propostas de participação da iniciativa privada no Sistema Penitenciário Brasileiro, que a execução penal não é dever de quem dita a pena e sim de quem a executa, ou seja, dos estabelecimentos penais. ${ }^{95}$ Assim sendo, a execução penal não seria uma continuação da Função Jurisdicional do Estado, não possuindo característica de função pública, mas sim de serviço público.

Na linguagem de Diogo de Figueiredo Moreira Neto:

“[...] serviço público é uma atividade da Administração que tem por fim assegurar, de modo permanente, contínuo e geral, a satisfação de necessidades essenciais ou secundárias da sociedade, assim por lei consideradas, e sob as considerações impostas unilateralmente pela própria Administração. "96

Já o saudoso e sempre atual jurista Hely Lopes Meirelles define serviços públicos como sendo:

\footnotetext{
“[...] todo aquele que é prestado pela Administração ou por seus delegados, sob normas e controles estatais, para satisfazer necessidades essenciais ou secundárias da coletividade ou simples conveniência do Estado. "97
}

Em sendo um serviço público, inexiste qualquer óbice à delegação da administração de uma unidade prisional à iniciativa privada. Ademais, o próprio Estado estará sempre vigilante para evitar desvio no cumprimento das obrigações contratuais, tanto que as propostas nacionais de participação da iniciativa privada no sistema prisional prevê a existência de um funcionário público nas dependências da unidade prisional, como se um Diretor Prisional fosse, tomando juntamente com a direção privada as decisões mais complexas e sendo os olhos e ouvidos do Estado junto a administração particular. ${ }^{98}$ Logo, a

\footnotetext{
${ }^{95}$ REIS, Ercília Rosana Carlos. “A privatização das prisões sob a ótica do direito administrativo”. Editora Revista dos Tribunais: São Paulo, 1995 p. 85

${ }^{96}$ MOREIRA NETO, Diogo de Figueiredo. Curso de Direito Administrativo. Rio de Janeiro: Forense, 1992. p.317.

${ }^{97}$ MEIRELLES, Hely Lopes. Direito Administrativo Brasileiro. São Paulo: Forense, 1993, p. 60-61.

${ }^{98}$ OLIVEIRA, Edmundo . O futuro alternativo das prisões. Rio de Janeiro : Forense, 2002, cit. p. 314.
} 
própria empresa terá interesse em mostrar zelo e eficiência, não só para garantir a manutenção do contrato, como também para merecer a credibilidade pública.

Uma das novidades da Lei de Execuções Penais - LEP (Lei $n^{\circ} 7.210$, de 11.07.1984) foi a previsão, no art. $4^{\circ}$, da possibilidade de o Estado recorrer à cooperação da comunidade para abrir novos caminhos na execução penal.

Efetivamente, em vários momentos, a LEP busca a participação dos diversos segmentos da sociedade, como por exemplo: na instalação do Conselho de Comunidade (art. 80 da LEP), na criação de Patronato Particular (art. 78 da LEP), na assistência à saúde do preso (art. 14, §2 $2^{\circ}$ da LEP), no convênio com entidades particulares para atividades educacionais (art. 20 da LEP), na assistência religiosa (art. 24 da LEP), na assistência jurídica (art. 15 da LEP), na atribuição de trabalho ao preso (art. 36 da LEP).

Imperioso ressaltar que, a natureza jurídica da execução penal envolve três ramos de atividade, senão vejamos: a) atividade jurisdicional, que compete ao juiz da execução penal, na qualidade de comandante da execução, para garantir o cumprimento das disposições legais fixadas pelo Direito Penal, pelo Direito Processual Penal e pela Constituição Federal (art. 66 da LEP); b) atividade administrativo-judiciária, a qual é exercida pelo servidor público, para os fins da relação jurídica estabelecida entre o preso e o Estado, que é o titular do jus puniendi. Situam-se, nesse conjunto, as tarefas pertinentes ao Ministério Público, ao Conselho Penitenciário e ao Departamento Penitenciário (arts. 67, 69 e 71 da LEP); c) atividade administrativa extrajudicial, que pode ser exercida por órgãos do próprio Estado ou por entidades privadas, conforme previsão em lei federal ou estadual. É o caso da promoção de trabalho e da assistência religiosa, jurídica, educacional e á saúde do preso (arts. 14, 15, 20, 24 e 36 da LEP). ${ }^{99}$

O exame da Lei de Execuções Penais produz a clara conclusão de que, ressalvadas as atividades jurisdicionais e as atividades administrativo-judiciárias, não há nenhum impedimento para a atuação de empresas, órgãos ou entidades privadas no gerenciamento ou realização de obras ou serviços que envolvam qualquer atividade administrativa extrajudicial na execução da pena. ${ }^{100}$

\footnotetext{
99 REIS, Ercília Rosana Carlos.“A privatização das prisões sob a ótica do direito administrativo”, Editora Revista dos Tribunais: São Paulo, 1995 p. 92

${ }^{100}$ Id. Ibid. p. 92
} 
Júlio Fabbrini Mirabete, em estudo realizado acerca da mencionada Lei de Execuções Penais (Lei n. 7.210 de 11.07.84), comenta a possibilidade legal de participação da iniciativa privada no sistema penitenciário:

"Em nenhum momento prevê (a lei) a obrigatoriedade de que os estabelecimentos penais sejam de propriedade do Estado, permitindo com isso que sejam os prédios pertencentes a empresas privadas em qualquer dos regimes jurídicos permitidos em lei." 101

Conhecendo-se a posição de Mirabete com relação ao monopólio do uso da violência por parte do Estado e sua titularidade única e exclusiva, ele próprio tem colocado que:

[...] não há dispositivo que vede a possibilidade da gerência e operação material dos estabelecimentos penais ser exercida por entidade privada. Em nenhum momento a lei federal dispõe que o diretor $e$ os servidores devam ser obrigatoriamente funcionários públicos. "102

Desse modo, conforme advoga Edmundo Oliveira:

“[...] é plenamente viável a alternativa de implementar a iniciativa privada, no setor prisional, através de normas federais ou estaduais que disciplinem a concessão e permissão de serviços públicos. Se a iniciativa privada for capaz de melhorar a assistência ao preso e reduzir custos, não tem porque gerar conflitos ou trazer complicações materiais para o desempenho do Poder Judiciário e do Poder Executivo, na administração prisional. (...) o essencial é saber organizar a conjunção inteligente da função jurisdicional $e \quad d a$ Administração Pública com a iniciativa privada, em condições de dar à execução penal o caráter de formação da cidadania, capaz de fundamentar a dignidade da pessoa presa, como ente apto a prover sua subsistência com autonomia $e$ criatividade. ",103

${ }^{101}$ MIRABETE, Julio Fabbrini. Execução Penal. $5^{\text {a }}$ Ed. Editora Atlas, São Paulo, 1995 p.114.

102 Id. Ibid. p. 114.

${ }^{103}$ OLIVEIRA, Edmundo . O futuro alternativo das prisões. Rio de Janeiro : Forense, 2002, cit. p.336. 
Utilizando-se, portanto, dessa forma mista de administração, em que ente estatal e privado atuarão de forma conjunta - este no exercício das atividades administrativas extrajudiciais e aquele nas atividades jurisdicionais e administrativo-judiciárias - superados encontram-se os impedimentos constitucionais (Art. 5º III e LII da CF/88) apresentados pela doutrina contrária a participação da iniciativa privada, visto que, em assim sendo, a empresa privada não terá qualquer participação no efetivo cumprimento de pena de detento, restringindo-se a idealizar projetos e realizar melhorias administrativas essenciais a consecução da finalidade primordial da pena: reinserção social. ${ }^{104}$

Para concluir a apresentação dos argumentos favoráveis à participação da iniciativa privada no sistema prisional, transcrevemos agora as impressões obtidas pelo Dr. Alvino Augusto de Sá, psicólogo do sistema penitenciário do Estado de São Paulo, em visita realizada a dois presídios terceirizados existentes em território nacional, onde, com muita simplicidade, sintetiza os posicionamentos anteriormente apresentados:

\begin{abstract}
“As características arquitetônicas dos presídios terceirizados que facilitam sua abertura e seu intercâmbio com o ambiente externo certamente acabam inspirando nos profissionais uma atitude favorável ao intercâmbio cárcere-sociedade, nas práticas penitenciárias. Seria aliás um aspecto interessante para se pesquisar. Em minhas visitas, meus contatos $e$ conversas, o que pude observar entre os profissionais foi uma predisposição favorável à participação de segmentos da sociedade. Tal participação não tinha sido implementada, certamente por falta de um aprimoramento técnico nesse sentido, já que experiências dessa ordem praticamente inexistem. Nas penitenciárias administradas pelo Estado, elas estão sujeitas a medidas burocráticas de trâmite não raramente moroso. Ainda que tais medidas se justifiquem, tudo seria facilitado caso houvesse, da parte dos administradores, uma real abertura para o intercâmbio com a sociedade. Nos presídios terceirizados, tal abertura pareceu-me existir. Uma hipótese que coloco (e que eu teria muito interesse de verificar mediante pesquisa de campo) é a seguinte: os profissionais penitenciários do Estado, sobretudo os da segurança, talvez entendam o ambiente carcerário e todos os seus problemas
\end{abstract}

104 REIS, Ercília Rosana Carlos. “A privatização das prisões sob a ótica do direito administrativo”. Editora Revista dos Tribunais: São Paulo, 1995 p. 94 
como sendo de sua posse exclusiva e exclusiva responsabilidade, sentindo-se eles no dever e direito de exercer sobre o cárcere e os presos total poder e controle, na medida em que têm sobre essa realidade um "saber" exclusivo. Hipoteticamente, repito, hipoteticamente, poderíamos estabelecer os seguintes nexos: a aprovação num concurso público dá ao candidato o direito de ser nomeado para o cargo, desde que existente a vaga. Nomeado, a vaga é sua, e ninguém tem o poder de tirá-la dele. Nomeado e tendo assumido sua vaga no cargo, o funcionário ou profissional automaticamente se investe do poder que lhe é conferido por força do exercício do cargo. Investido no cargo (poder), ele (tanto na sua subjetividade, como na de outros) passa a ser alguém diferente dos demais, ou seja, ele pode e deve, a partir desse momento, tomar medidas e decisões que, se tomadas por outras pessoas (da sociedade), não teriam valor legal, não seriam legitimadas pelo poder público. Consequentemente, os funcionários do Estado, por uma espécie de consenso, seriam os verdadeiros "titulares" no exercício profissional penitenciário, pelo que a participação de outras pessoas não pertencentes ao meio carcerário seria por eles tida como não legítimas e, quem sabe, até mesmo como ameaça à exclusividade de seu "saber" e à titularidade de seu "poder". Por outro lado, os profissionais dos presídios terceirizados, contratados pela empresa que os administra, talvez se sintam “contratados para” e não "concursados”, não se vejam como titulares de um saber e poder exclusivos e nem pessoas especialmente destacadas e diferenciadas da sociedade para exercer essa função. Seu poder está legitimado unicamente no âmbito restrito da empresa, não lhes é “imamente” e lhes pode ser retirado a qualquer instante, a critério da empresa. Quanto ao poder da empresa, poderíamos dizer que ele é legitimado pelo Diretor do presídio. Nomeado pelo Estado, cujo poder, portanto, tem legitimação pública. Os direitos que os profissionais da empresa têm são de natureza unicamente trabalhista. Assim, é provável que, para eles, seja mais fácil aceitar a presença e participação de segmentos da comunidade, já que as únicas diferenças é que as pessoas desses segmentos não teriam um treinamento especializado e não estariam ligadas à empresa. Resumindo e concluindo esta 
questão, nos presídios terceirizados o clima pareceu-me mais favorável à abertura do cárcere para a sociedade, e é possivel que essa vantagem se deva ao fato de que seus profissionais se sintam antes uma extensão da sociedade dentro cárcere, e não titulares de um saber e poder exclusivos." 105

\subsubsection{Argumentos políticos}

Sob o aspecto político, o impedimento mais comumente levantado, como já vimos anteriormente se consubstancia nas palavras de Minhoto, em resumo o receio do surgimento de um mercado correcional, traria incentivo para que as empresas interessadas nos contratos públicos fizessem lobby para que mais prisões fossem construídas, bem como para que as penas se tornassem mais rígidas, já que tais medidas acabariam por aumentar o lucro das empresas.

Ocorre que tal argumento não é na verdade, uma crítica à participação de empresas privadas na gestão prisional, mas sim uma boa justificativa para reformas no nosso atual sistema político, dentro qual grupos de interesses especiais (sindicatos, entidades empresariais, "movimentos sociais" em geral) se enriquecem da res publica em nome de ganhos privados. ${ }^{106}$

Se faz necessária a existência de mecanismos de controle e transparência que facilitem o acesso às informações referentes aos negócios de interesse público e aos seus agentes, para que possa, de fato, existir um controle público sobre a classe política. Nesse sentido, entidades como a Transparência Internacional e o website Contas Abertas ${ }^{107}$ devem ser louvadas como sinal da iniciativa e capacidade de mobilização da sociedade civil. Desse modo, se a população não desejar penas mais severas o maior controle sobre a agenda política (criminal) tenderá a inviabilizar o lobby praticado pelas empresas correcionais, ou ao menos diminuir drasticamente suas chances de êxito.

Ademais, este argumento ignora o fato de que servidores públicos buscam influenciar decisões políticas guiados por seus interesses privados - e o fazem com razoável sucesso.

\footnotetext{
${ }^{105}$ SÁ, Alvino Augusto de. Op. cit..

106 MINHOTO, Laurindo Dias. Privatização de Presídios e Criminalidade: a gestão da violência no capitalismo global. São Paulo: Max Limonad, 2000 p. 121.

${ }^{107}$ Disponíveis, respectivamente, em <www.transparencia.org.br> e http://contasabertas.uol.com.br.. Acesso em 12/08/2013.
} 


\section{CAPÍTULO IV}

\section{A PRIVATIZAÇÃO DO SISTEMA PRISIONAL}

O que mais escutamos falar atualmente é em reforma do Estado, reforma na Administração Pública, a transparência nos procedimentos de controle do Estado. A reformulação do Estado traz consigo a flexibilização da Administração Pública, a descentralização do poder, e a mudança da posição de prestadora de serviço para o gerenciamento, supervisão e fiscalização dos serviços, antes oferecido pela administração, transferida à terceiros. ${ }^{108}$

Com a desestatização do Estado verifica-se o aparecimento de novos princípios de gestão. A privatização torna-se uma ferramenta de mudança, que visa a desburocratização da máquina estatal, transferindo as ações do Estado para empresas privadas. ${ }^{109}$

A privatização é um processo aberto que tem por objetivo reduzir os encargos do Estado e fortalecer a iniciativa privada e as formas privadas de gestão e serviços públicos. Várias técnicas são aplicadas como: concessão de serviços de obras públicas, modos de parcerias como setor privado, parceria público-privada e etc. ${ }^{110}$

Essas formas de desburocratização são propostas para a Administração Pública constituindo formas de privatizar.

Francisco José Villar Rojas inclui como das técnicas de privatização: “a contratação de serviços e atividades antes geridos diretamente". ${ }^{111}$

Entretanto, podemos considerar que no sentido amplo a terceirização é uma forma de privatização. Atualmente é muito utilizada pela Administração Pública que busca parceria com o setor privado para a realização das suas atividades.

\footnotetext{
${ }^{108}$ MOREIRA NETO, Diogo Figueredo. Curso de Direito Administrativo. 10 a ed. Ed. Forense - Rio de Janeiro: Ed. 1992. p. 16

${ }^{111}$ ROJAS, Francisco José Villar. "Privatizaciòn de Servicios Públicos", Madrid, 1993, pág. 10
} 
A terceirização dos serviços públicos demonstra que o Estado tem como objetivo a procura de uma liberdade nos procedimentos da atividade administrativa do Estado, principalmente no que tange o regime jurídico que é imposto hoje à Administração Pública. ${ }^{112}$

A terceirização pode ser utilizada desde a empreitada de obras e de serviços, ao fornecimento de mão-de-obra, a franquia, a administração de penitenciárias. ${ }^{113}$

A questão de terceirização de presídios ou a privatização do sistema penitenciário, como já mencionado anteriormente, surge a partir da falência da pena de prisão. 114 A situação do sistema carcerário não é um problema percebido somente em nosso país, mas em todo mundo. Este problema social é um dos mais complexos e relevantes atualmente, tal problemática envolve uma série de pontos fundamentais que levam ao fortalecimento da idéia de terceirização dos presídios.

Com a consolidação da pena privativa de liberdade houve um inchaço nos estabelecimentos penais, esse crescimento vem aliado ao despreparo e a falta de planejamento para acomodar os apenados e executar a pena. A falta de estrutura física concilia-se com a ineficiência da Administração Pública em gerenciar o setor prisional. ${ }^{115}$

O investimento é um dos pontos cruciais quando se trata do problema do sistema prisional, as verbas são essenciais para construções e reaparelhamento das unidades prisionais. ${ }^{116}$

A terceirização dos presídios compreende na transferência da administração das unidades prisionais para uma empresa privada que passa a executar as atividades-meio (alimentação, limpeza, segurança interna, etc.), uma vez que não se transfere a função jurisdicional do Estado, na qual é indelegável em nosso país. Como citado anteriormente, o Estado muda de posição e passa a gerenciar a prestação de serviços, fiscalizando, controlando as atividades que foi transferida a terceiros. As políticas e diretrizes adotadas dentro dos estabelecimentos penais continuam a ser do Estado, este tipo de serviço prestado por empresas particulares junto com o Estado é denominada Parceria Público-Privada (PPP). ${ }^{117}$

Muitos países da Europa utilizam esta terceirização parcial dos estabelecimentos penais e a experiência continua sendo positiva. A variação dos custos de

\footnotetext{
112 MOREIRA NETO, Diogo de Figueiredo. O Sistema de Parceria entre os Setores Públicos e Privado. In: Boletim de Direito Administrativo. São Paulo, 1996. p. 75

113 Id. Ibid. p. 75-81.

${ }^{114}$ MINHOTO, Laurindo Dias. Privatização de Presídios e Criminalidade. São Paulo: Max Limonad, 2000, cit. p.55.

115 Id. Ibid. p.57.

116 REIS Ercília Rosana Carlos. Privatização das Prisões - A Privatização das Prisões sob a Ótica do Direito Administrativo. São Paulo: Revista dos Tribunais, 1995, p. 48

${ }^{117}$ RIBEIRO, Armando Lúcio. Privatização (Terceirização) dos Presídios. Disponível em

<http://www.mp.rn.gov.br/artigo/caops/caopjp/teses/privatizacao_presidios.pdf. >Acesso em 10 de agosto de 2013.
} 
investimentos implicará no aspecto do padrão da construção ou no modelo de prisão, que vão da necessidade de adotar tecnologia de sistema de segurança a barreiras físicas. ${ }^{118}$

O que se espera é uma redução de custos de investimentos e de operação dos presídios, já que o descumprimento da Lei de Execução Penal é gritante e a desestrutura operacional é evidente. ${ }^{119}$

A superlotação dos estabelecimentos penais, a corrupção, a fragilidade da segurança, cercada por organizações criminosas que assolam o sistema prisional, reforça o descumprimento da função do Estado, no âmbito prisional, que é a custódia e a ressocialização do indivíduo que infringiu as normas de conduta social estabelecida em lei. Todavia a ressocialização deve estar ligada na humanização do indivíduo infrator que deve possuir condições de ser inserido na sociedade.

\subsection{Formas de terceirização}

As formas de prestação de serviço de custódia apresentada pelas empresas privadas vão desde a terceirização parcial até a privatização total do sistema prisional, estas propostas são colocadas como soluções eficientes e econômicas para o Estado, devido a desburocratização administrativa, redução de custos e a construção de estabelecimentos penais entregues no tempo previsto e determinado. A construção de estabelecimentos penais é um dos pontos cruciais para desafogar o sistema penitenciário brasileiro que se encontra inchado. ${ }^{120}$

As possibilidades de execução dessa nova proposta deve ser analisada com cuidado, haja vista que se encontram entraves na relação com as práticas jurídicas administrativas estabelecidas em lei em nosso país.

As formas de terceirização se dividem em quatro maneiras:

1. A empresa privada constrói o estabelecimento penal e depois aluga para o Estado que administrará.

2. A empresa privada oferece serviços ao Estado, como fornecimento de alimentação, limpeza, educação, etc., por meio de licitação. No caso de alimentação a empresa fica responsável pela instalação da cozinha dentro das unidades prisionais.

\footnotetext{
118 RIBEIRO, Armando Lúcio. Privatização (Terceirização) dos Presídios. Disponível em <http://www.mp.rn.gov.br/artigo/caops/caopjp/teses/privatizacao_presidios.pdf.> Acesso em 10 de agosto de 2013.

119 MACHADO, Ricardo. Privatização (gestão privada) ou co-gestão do Sistema Penitenciário Brasileiro?. Instituto Teotônio Vilela, Brasília, DF, 2000, p. 7

${ }^{120}$ Id. Ibid. p. 7
} 
3. A empresa privada faz todo o processo de custódia, ou seja, há a privatização da custódia onde a empresa se responsabiliza pela construção, instalação de materiais (equipamento de segurança, móveis e outros), manutenção da unidade, fornecimento de recursos materiais ao preso (alimentação, roupas, artigos de higiene e limpeza), contratação de funcionários. A empresa recebe os presos do Estado e passa a fazer a gestão de todo o procedimento de custódia e ressocialização do indivíduo.

4. Os estabelecimentos penais são construídos pelo Estado ou por empresários, é feita uma parceria onde o Estado entrega toda a parte de infra-estrutura tanto física como material para a empresa privada que usufrui do trabalho dos internos nos campos industrial, é a chamada Prisão-industrial. ${ }^{121}$

Como vimos anteriormente a terceira forma de participação das empresas privadas no setor carcerário não é interessante para o nosso país, uma vez que se tornaria anticonstitucional cuja a função de custódia é indelegável, impossibilitando a transferência de custódia e ressocialização do apenado para uma empresa privada. A privatização total não é considerada viável e é muito questionável por estudiosos, legisladores e aqueles que defendem e respeitam os direitos humanos. ${ }^{122}$

Os países que adotaram este modelo de gestão e privatizaram todo o sistema carcerário como os Estados Unidos e Inglaterra já estão dando sinais de esgotamento. Segundo Loic Wacquant sociólogo francês, radicado nos Estados Unidos e um dos maiores nomes de estudiosos que pesquisam o sistema penitenciário, afirma que a privatização do sistema prisional abriu margens para a indústria de castigo, onde o interesse privado aliado com o capitalismo turbinado, alto índices de desemprego e altas taxas de criminalidade cria um ambiente cativo para a exploração em massa dos que cumprem pena privativa de liberdade. Para ele nos Estados Unidos se instalou uma gestão penal de miséria, um modelo ilusório que vem sendo copiado por países de terceiro mundo onde seus resultados podem ser mais destrutivos e negativos. ${ }^{123}$

O que se alega no Brasil é que tal estratégia de gestão reduziria custos e melhoraria os serviços que são prestados aos internos fazendo cumprir até então o que é estipulado pela Lei de Execução Penal. Se houvesse o cumprimento da Lei de Execução Penal já daríamos um passo avançado para melhorar os nossos ambientes carcerários e

\footnotetext{
${ }^{121}$ MINHOTO, Laurindo Dias. Privatização de Presídios e Criminalidade: a gestão da violência no capitalismo global. São Paulo: Max Limonad, 2000 p. 98.

122 OTTOBONI, Mário. A questão da Privatização das Prisões. Paulinas São Paulo-SP, 1992 p. 43.

${ }^{123}$ WACQUANT, Loïc. As Prisões da Miséria. Rio de Janeiro: Jorge Zahar, 2001, pág 32.
} 
começaríamos a efetivar o processo que se tanto fala dentro do sistema penitenciário a "ressocialização", papel pelo qual compete ao Estado-administração, atuante através de seus órgãos a realização da integração social. ${ }^{124}$

O artigo $1^{\circ}$ da Lei n. ${ }^{\circ}$ 7.210/84, dispõe "A execução penal tem por objetivo efetivar as disposições de sentença ou decisão criminal e proporcionar condições para a harmônica integração social do condenado e do internado". Nota-se que o foco da lei não é a punição ou o castigo e sim a reabilitação dos apenados para voltar a vida em sociedade.

Logo a legislação estabelece a individualização da pena, o direito substantivos e processuais dos custodiados, direitos humanos, garantindo a assistência jurídica, religiosa, médica, psicológica, social e material do apenado. As regras mínimas para tratamento do preso de 1994 se baseou nas Regras Mínimas para Tratamento dos Prisioneiros das Nações Unidas, e é considerada "guia essencial" para aqueles que militam na administração de prisões. ${ }^{125}$

A terceirização na forma que vem sendo aplicada no Brasil é questionável, pois fere os princípios básicos da Administração Pública, mas pode ser legitimada se for comprovado a redução de custos tanto para o Estado quanto para o contribuinte, precisamos considerar as conseqüências ou contribuições positivas e negativas do novo modelo de gerenciamento do sistema penitenciário. ${ }^{126}$

\subsection{Privatização do Sistema Prisional Adotado em outros Estados Brasileiros e Países.}

Após o ápice do vislumbramento do processo de privatização do sistema penitenciário americano, o encarceramento tornou-se um comércio rentável, que emprega um grande número de pessoas. Esta nova economia converte em controle para grupos de empresários que investem neste setor. ${ }^{127}$

O cárcere constitui-se como um dos grandes motores que levanta o desenvolvimento da indústria contra o crime, ${ }^{128}$ principalmente nos tempos onde o desemprego alcança níveis elevados, e a insegurança social com as políticas ineficazes dos

\footnotetext{
124 MACHADO, Ricardo. Privatização (gestão privada) ou co-gestão do Sistema Penitenciário Brasileiro?. Instituto Teotônio Vilela, Brasília, DF, 2000, p. 20.

${ }^{125}$ MINHOTO, Laurindo Dias. Privatização de Presídios e Criminalidade: a gestão da violência no capitalismo global. São Paulo: Max Limonad, 2000 p. 100.

${ }^{126}$ LEMGRUBER, Julita. O sistema penitenciário brasileiro. Cidadania e justiça. $1^{\circ}$ sem 2001, p.170.

127 GOMES, Luiz Flávio. Indústria das prisões. Jus Navigandi, Teresina, ano 12, n. 1318, 9 fev. 2007. Disponível em: <http://jus.uol.com.br/revista/texto/9478>. Acesso em: 17/07/13.

${ }^{128}$ Id. Ibid. <http://jus.uol.com.br/revista/texto/9478>. Acesso em: 17/07/13.
} 
órgãos responsáveis pela segurança pública, promove uma corrida armamentista dos cidadãos que estão preocupados com a própria integridade física.

As prisões privadas estão despertando polêmica principalmente na sua proposta de eficiência, redução de custos, a delegação da custódia do apenado para empresas privadas.

A criminalidade é uma das razões pela qual os americanos assumem a prática de sentenciamentos mais rigorosa, a construção de presídios de segurança máxima e o tratamento de encarceramento de jovens com alto impacto social, coloca o sistema penitenciário contemporâneo americano como uma "galinha de ovos de ouro" para o mercado industrial das prisões. ${ }^{129}$

Reforçado por uma política institucional com projetos neoliberal a diminuição da atuação do Estado na ordem social substituído por modelos de estratégias de outras leis e ordem, ${ }^{130} \mathrm{a}$ idéia de privatização de presídios se encaixa perfeitamente.

No Brasil, o estado do Paraná foi um dos pioneiros no processo de privatização dos estabelecimentos penais, no período de 1999 e 2002 foram construídas seis penitenciárias destinadas a administração de empresas terceirizadas. ${ }^{131}$

A primeira foi a Penitenciária Industrial de Guarapuava, logo depois vieram a Penitenciária Estadual de Cascavel, a Penitenciária Estadual de Piraquara, a Penitenciária Estadual de Foz do Iguaçu, duas Casa de Custódia de Curitiba e Londrina. ${ }^{132}$

As inaugurações das penitenciárias foram acompanhadas de fortes e favoráveis discursos do governo pela administração do sistema penitenciário. Pedro Rodolfo Bodê de Moraes doutor em sociologia e atualmente Professor adjunto no Departamento de Ciências Sociais da Universidade Federal do Paraná, proferiu o seguinte discurso:

\footnotetext{
“ as Penitenciárias Industriais fazem parte de um projeto do Governo do Paraná, que prevê parcerias com a iniciativa privada, objetivando uma mudança na concepção de penitenciarismo, através da construção de penitenciárias com mais espaço para canteiros de trabalho, com real oportunidade de reintegração social pela profissionalização
}

\footnotetext{
${ }^{129}$ Id. Ibid. Acesso em 10 de agosto de 2013.

${ }^{130}$ LEMGRUBER, Julita. O sistema penitenciário brasileiro. Cidadania e justiça. $1^{\circ}$ sem 2001, p.170.

${ }^{131}$ ARAUJO JUNIOR, João Marcello de. Privatização das prisões. São Paulo: RT, 1995. p. 42

132 DEPARTAMENTO Penitenciário do Paraná. Disponível em:

$<$ http://www.depen.pr.gov.br/modules/conteudo/conteudo.php?conteudo=36>aacesso em 21/10/13.
} 
dos presos (...) concebia dentro de um projeto arquitetônico bastante diferenciado dos presídios tradicionais, uma das maiores inovações é, sem dúvida, a garantia de atividades profissionalizantes aos presos que, deixando de lado a ocupação artesanal, passam a ter uma qualificação profissional. Isto permite que ele se reeduque e se integre a sociedade quando do cumprimento de sua pena (...) com o mesmo perfil estético de uma fábrica, as Penitenciárias Industriais contam com equipamentos modernos, instalados pelos próprios empresários, parceiros deste novo conceito de tratamento penitenciário, de largo alcance social. (...) Participando do projeto, a iniciativa privada obtém excelentes resultados de produtividade, lucratividade e uma boa imagem para a sua empresa, além da vantagem de utilizar mão-deobra dos presos, dando-lhes dignidade e uma nova chance de reintegração social. ",133

\subsection{As Empresas que atuam na Administração de Unidades Prisionais}

Hoje no Brasil existem empresas que atuam nesse ramo, como a INAP, Montesinos, Humanitas, CONAP, Reviver e Yumatã. ${ }^{134}$ Através do material colhido do website da ASPRA (Associação dos Praças Policiais e Bombeiros Militares de Minas Gerais), pegaremos como por exemplo a proposta da empresa INAP (Instituto Nacional de Administração Prisional) onde seu slogan é "Trabalho para Liberdade".

O sistema adotado pela empresa é baseado nos modelos americanos e de alguns países europeus. Sua atuação é conjunta com o governo que oferece amparo legal e a instalação. A empresa trabalha com outra empresa distinta que é responsável normalmente pela indústria, oferecendo treinamento e matéria-prima para usufruir da mão-de-obra dos internos. A INAP cuida das funções operacionais, a guarda e assistência aos detentos.

A INAP se considera como uma empresa capacitada que trabalha com a punição e reabilitação em conjunto. A empresa presta serviços assistenciais como: atendimento médico, odontológico, jurídico, serviço social, e faz a complementação

\footnotetext{
133 MORAES Pedro Rodolfo Bordê de. Punição, encarceramento e construção de identidade profissional entre agentes penitenciários, p. 142.

${ }^{134}$ SANTOS, Jorge Amaral dos. As parcerias público-privadas no sistema penitenciário brasileiro. Jus Navigandi, Teresina, ano 14, n. 2269, 17 set. 2009. Disponível em: <http://jus.uol.com.br/revista/texto/13521〉. Acesso em: 10/10/13.
} 
educacional nos níveis fundamental e médio, remuneração para os internos, e segurança. Responsável pela alimentação, limpeza, vestuário, material de higiene dos detentos.

As empresas que prestam estes tipos de serviços geralmente advém de empresas com experiência na área de segurança privada, vigilância comercial, industrial e patrimonial, por isso há a necessidade de avaliação e principalmente de supervisão estreita das atividades prestadas para a administração penitenciária estadual.

A contratação dessa empresa é feito por meio de processo licitatório, onde é estabelecido requisitos para habilitação das mesmas no segmento de mercado que irão atuar. $^{135}$

135 DISPONÍVEL em :<http://www.aspra.org.br/index.php?option=com_content\&view=article\&id=523:clipping-diario130309\&catid=16:deu-na-midia\&Itemid=6 > Acesso em: 11/10/13. 


\section{CONCLUSÃO}

Através da análise histórica do sistema penitenciário, pode-se constatar que a pena desde seu surgimento até os dias atuais, sofreu grande evolução: da pena corporal passamos para a pena privativa de liberdade. Na primeira modalidade (corporal), a pena era o castigo e o condenado era colocado como objeto na execução penal. Com o aumento da criminalidade, com a elevação do número de crimes contra o patrimônio e a redução dos crimes violentos, as penas corporais tornaram-se inviáveis e foram substituídas pelas penas privativas de liberdade.

Nessa primeira fase, prendiam-se as pessoas pelos pés, pelas mãos, pelo pescoço etc. homens e animais, do mesmo modo, eram amarrados, acorrentados, manietados, grilhetados. Cavernas, subterrâneos, túmulos, fossas, torres, troncos, esteios, tudo servia para privar a liberdade.

Com a característica de pena, a prisão apareceu na Idade Média, quando então, castelos, fortalezas e conventos mantinham espaço como prisão. Vieram, em seguida as galés ou galeras, os presídios militares e os presídios de obras públicas.

No século XVIII, graças aos talentos de John Howard e Cesare Beccaria, aconteceu o início do Período Humanitário das prisões, gerando uma série de movimentos de reforma, que se estenderam na Europa, durante os séculos XVIII e XIX, combatendo a dureza dos cárceres, a compilação dos processos investigatórios, o atraso dos aparelhos judiciários e a falta de idoneidade das prisões como local para cumprir a pena ressocializadora. No século XX, ocorreu o chamado Período Científico da Prisão.

As idéias de John Howard, Cesare Beccaria e Jeremias Bentham deram origem à formação dos Regimes Penitenciários Clássicos, concebidos sob a base de sistemas diferenciados de reeducação, os quais prosperaram a partir do século XIX. Os Sistemas Penitenciários Clássicos, que prosperaram nos Estados Unidos, na Europa e serviram de modelo para os demais países do mundo, a partir do século XIX, foram os seguintes: Sistema Pensilvânico; Sistema Auburniano; Sistema Progressivo Inglês; Sistema Progressivo Irlandês; Sistema de Elmira; Sistema de Montesinos e o Sistema Borstal.

Não há dúvida de que enorme foi o esforço dos Sistemas Penitenciários Clássicos, no sentido de adotar o modelo de privação de liberdade com crescentes iniciativas, 
visando aliviar o pesadelo da contínua violação dos direitos humanos nos cárceres e possibilitando, igualmente, a real correção dos delinquentes.

Os resultados práticos não geraram a mais produtiva e infalíveis experiências, todavia valeu a contribuição desses sistemas clássicos, como ingrediente merecedor de reconhecimento, na luta incessante em busca de prestígio para o processo regenerador que a anormalidade prisional não merece alcançar.

Não há mais dúvidas de que o sistema penitenciário brasileiro está falido, além de inútil como solução para os problemas da criminalidade. Neles os direitos humanos previstos na Constituição Federal são totalmente desrespeitados.

Todos esses problemas, aliados as experiências estrangeiras bem sucedidas ensejam a idéia de participação da iniciativa privada no sistema prisional brasileiro, o que tem sido objeto de ferrenhas discussões doutrinárias.

A literatura aponta basicamente quatro modalidades distintas de envolvimento privado, voltado ao lucro, na esfera penitenciária: a) o financiamento e/ou construção de novos estabelecimentos; b) a provisão de serviços penitenciários, tais como educação, saúde, profissionalização, alimentação, vestuário, etc.; c) a administração total de estabelecimentos penitenciários, que pode ser contratada somente para gestão de presídios já existentes, ou combinado as várias modalidades, para o financiamento, construção e operação de novos estabelecimentos; d) a administração do trabalho prisional (prisões industriais).

Em alguns lugares já vem sendo utilizada experimentalmente. Como na Inglaterra, Estados Unidos e França. Em cada um desses países assumiu-se características próprias.

Nos Estados Unidos existem três formas de participação da iniciativa privada no sistema penitenciário: a Gestão Privada Total, a Gestão Privada Compartilhada e a Gestão Privada Compartilhada para Fase Final da Pena. Em síntese, os serviços privados, nos estabelecimentos prisionais norte-americanos, envolvem notadamente: a alimentação , a lavanderia, o transporte, a segurança, a atividade religiosa, a convalescença, o trabalho, a formação pessoal, a assistência jurídica, o tratamento médico, a informática, o teatro, a dança, a cantina, a venda de objetos, o banco de sangue, a terapia dos delinquentes sexuais ou por uso de drogas e a produção industrial destinada às empresas privadas.

$\mathrm{Na}$ Inglaterra, o processo de privatização do sistema penal iniciou com a construção dos estabelecimentos para presos provisórios pela iniciativa privada. Entretanto, a tendência é a de incrementar o programa de privatização para abranger as demais áreas do sistema penitenciário, de acordo com o conceito mais amplo de privatização que abrange 
serviços, alimentação e direção do estabelecimento. Portanto, contrariamente aos rumos que o processo de privatização vem tomando nos Estados Unidos, onde já há uma diretriz que limita o conceito de privatização à contratação de serviços e aquisição de bens com empresa privada, na Grã-Bretanha a diretriz principal da política penitenciária segue o rumo à tendência de privatização total do sistema.

O projeto de privatização do sistema penitenciário francês teve inicialmente como objeto a edificação de prisões e, posteriormente, na execução de certas atividades, tal como a organização do trabalho, da educação, do lazer, da alimentação, do fornecimento de vestimentas, a guarda e demais serviços relacionados com o preso, incluindo assistência médica, social e jurídica, inclusive a segurança interna da instituição prisional (agentes carcerários). Ao Estado incube a indicação do Diretor Geral do estabelecimento, seu relacionamento com o juízo da execução penal e a responsabilidade pela segurança externa das instituições penitenciárias (função da Polícia do Estado). Dentre as unidades prisionais administradas pela iniciativa privada, existem prisões industriais para fabricações de móveis, roupas e calçados; prisão industrial para confecção de uva e mel; prisões com oficinas de conserto de equipamentos de informática; prisão-escola para ensinar ofício, como motorista profissional ou técnico em informática.

As propostas de participação da iniciativa privada no sistema prisional brasileiro prevêem a implantação sob a forma mista de gestão, envolvendo a administração pública e a privada representada por grupos ou empresas particulares instaladas no país. É a chamada terceirização.

A literatura contrária a participação da iniciativa privada no sistema prisional brasileiro aduz os seguintes argumentos visando fundamentar sua postura doutrinária: o dever constitucional de punir e recuperar delinquentes é exclusivo do Estado; a execução penal é função pública e não serviço público, sendo indelegável portanto; inexistência de contrato administrativo que regulamente a contratação da empresa privada; a administração penitenciária, como questão de segurança pública, é dever do Estado; a preocupação da iniciativa privada é o lucro e não o interesse na reinserção social do delinquente; risco de aumentar o número de encarcerados, visando maior obtenção de lucros pela iniciativa privada; implantação de trabalho forçado, sem livre adesão do preso; perigo de participação do crime organizado na administração particular; subestimação da pedagogia penitenciária pela empresa privada visando maior lucrabilidade; recusa em aceitar presos de maior periculosidade; ausência de investimento no progresso pessoal do preso, optando por mão-deobra limitada intelectualmente e não esclarecida. 
Em contrapartida, os favoráveis apresentam os seguintes argumentos visando viabilizar a participação da iniciativa privada no sistema prisional brasileiro: o Estado já demonstrou a sua incompetência diante da administração penitenciária, deixando de realizar investimentos necessários a manutenção ou modernização das instituições; resistir a privatização, é concordar com o caos implantado; a empresa privada dispõe de maior agilidade para administrar, liberadas da burocracia; a iniciativa privada, ao mesmo tempo que oferece melhores condições de trabalho aos seus funcionários e conta com profissionais capacitado, ainda garante trabalho remunerado ao preso, sem a contaminação da ociosidade, abrindo-se concreta possibilidade de ser absorvido pelo mercado de trabalho ao término do cumprimento da pena; as empresas privadas otimizam os serviços na busca de reduzir gastos, sem entretanto abdicarem da qualidade no fornecimento dos serviços contratados, sob pena de rescisão contratual; na empresa privada; o problema da corrupção interna ocorre em menor grau em relação á administração Estatal, possibilitando ainda a iniciativa privada a imediata demissão do funcionário corrupto, visto que a mencionada relação de trabalho estará sendo regulamentada pela CLT e não pelo Estatuto dos Servidores Públicos, onde a demissão por justa causa depende de procedimento administrativo mais complexo; a economia obtida pelo Estado com a transferência das atividades administrativas extrajudiciais a iniciativa privada gerará receitas que poderão ser aplicadas em outros setores da sociedade, igualmente carentes.

No decorrer deste trabalho de pesquisa, pode-se observar que defendemos a parceria com a iniciativa privada, técnica administrativa largamente utilizada, que poderia com brevidade colaborar com essa função estatal. Nossa posição é pela adoção de mecanismos de parceria do Estado com a iniciativa privada, desde que para tanto não seja ferido o que é indelegável, preocupação que todos podemos ter, para não comprometer qualquer proposta de privatização ou terceirização.

O desafio de definir adequadamente a participação da iniciativa privada no setor público, com uma única expressão, revela dificuldades, pois tanto denominando-se terceirização, privatização, parceria, co-gestão, ou qualquer outra, a questão nuclear é exatamente a mesma, com pequenas variações, sendo portanto, de qualquer forma bem-vinda.

A execução da pena, como dissemos anteriormente, compreende dois setores distintos, um da função jurisdicional e outro da chamada função material, que enseja a administração dos serviços gerais, como hotelaria, limpeza, armazenamento, etc.

É evidente que quanto mais o Estado realiza suas funções básicas, melhor as desempenhará, entregando a quem possa colaborar, com eficiência, as funções que não lhe 
são básicas, portanto delegáveis. Cremos que pela colaboração da iniciativa privada teremos a oportunidade de verificar um aprimoramento da mão-de-obra no setor, especializando-a.

Quanto a ociosidade a quem o preso é submetido, como dissemos anteriormente, a iniciativa privada tem plenas condições de reverter esse quadro angustiante, trazendo trabalho para a massa carcerária, remunerando-se nos padrões ditados pela Lei de Execuções Penais.

O egresso é outra preocupação que sempre ronda o sistema prisional, pois de nada vale o esforço durante o cumprimento da pena, se após a mesma, a sociedade nega ao egresso uma única oportunidade, remetendo-o à vida na clandestinidade, ante-sala da criminalidade.

Assim, quer pelas economias que se vislumbra, quer pelas inúmeras condições favoráveis que a iniciativa privada traria, é que se recomenda cada vez mais a integração da comunidade, da iniciativa com o Estado e com o próprio preso.

O que não se pode é aceitar as atuais condições estruturais e administrativas do sistema prisional brasileiro. É evidente que não se deve realizar contratos de gestão mista em todas as unidades prisionais existentes no território nacional de um dia para o outro. Para isso existem as experiências. Estas devem ser realizadas, pois só assim haverá dados capazes de dizer-nos se a fórmula de gestão mista obtém ou não êxitos, é ou não viável. Porém, se após realizadas experiências caracterizar-se ineficaz ou inviável a participação da iniciativa privada no sistema prisional brasileiro, certo será que algum benefício esta trouxe ao sistema penitenciário nacional, pois não há como piorar a atual situação. 


\section{REFERÊNCIAS BIBLIOGRÁFICAS}

ARAUJO JUNIOR, João Marcello de. Privatização das prisões. $2^{\circ}$ Ed. São Paulo, 2009.

BERG, Julie. Private prisons: International experiences and South African prospects.

CAPEZ, Fernando. Curso de Processo Penal. 17ª ed. Saraiva, São Paulo 2010.

D’URSO, Luiz Flávio Borges. A privatização de presídios: uma breve reflexão. Disponível em: < http://www.eknippel.adv.br/default.asp?ACT=s\&content=43\&id=32\&mnu=32>

DEL PONT, Marco. Penologia y Sistemas Carcelarios. Buenos Aires. Ediciones Depalma, 1974.

DI PIETRO, Maria Sylvia Zanella. Parcerias na administração pública. São Paulo: Atlas, 2002. Disponível em http://web.uct.ac.za/depts/sjrp/publicat/pripris.pdf.

FALCONI, Romeu. Sistema Presidial: Reinserção Social? São Paulo: Ícone, 1998.

FOUCAULT, Michel. Vigiar e Punir. 11 ed., São Paulo: Vozes, 1977.

FRAGOSO, Heleno Cláudio. Lições de Direito Penal. 7 ed., São Paulo: Forense, 1985, v.1.

GOMES, Luiz Flávio. Indústria das prisões. Jus Navigandi, Teresina, ano 12, n. 1318, 9 fev. 2007. Disponível em: 〈http://jus.uol.com.br/revista/texto/9478>.

GOULART, Henry. A individualização da Pena no Direito. São Paulo. Ed. Brasileira de Direito, 1975.

KOOGAN/HOUAISS. Enciclopédia e dicionário. Delta. 4ed. Rio de Janeiro. 2000.

LEMGRUBER, Julita. O sistema penitenciário brasileiro. Cidadania e justiça. $1^{\circ}$ sem 2001.

MACHADO, Ricardo. Privatização (gestão privada) ou co-gestão do Sistema Penitenciário Brasileiro?. Instituto Teotônio Vilela, Brasília, DF, 2000.

MARQUES, José Frederico. Curso de Direto Penal. São Paulo: Saraiva, 1953.

MEIRELLES, Hely Lopes. Direito Administrativo Brasileiro. São Paulo: Forense, 1993.

MINHOTO, Laurindo Dias. Privatização de Presídios e Criminalidade. São Paulo: Max Limonad, 2000.

MIRABETE, Julio Fabbrini. Execução Penal. 5a Ed. Editora Atlas, São Paulo, 1995 p. 28. 
MORAES Pedro Rodolfo Bordê de. Punição, encarceramento e construção de identidade profissional entre agentes penitenciários.

MOREIRA NETO, Diogo de Figueiredo. Curso de Direito Administrativo. Rio de Janeiro: Forense, 1992.

MOTTA, Carlos Pinto Coelho. Eficácia nas Licitações e Contratos. $11^{\mathrm{a}}$ Ed. Del Rey, Belo Horizonte, 2010 .

NUCCI, Guilherme de Souza. Manual de Processo Penal e Execução Penal. 6a. ed. vol.1 São Paulo: Revista dos Tribunais, 2010.

OLIVEIRA, Edmundo. O Futuro Alternativo das Prisões. 1 ed., Rio de Janeiro: Forense, 2002.

OTTOBONI, Mário. A questão da Privatização das Prisões. Paulinas São Paulo-SP, 1992.

REIS, Ercília Rosana Carlos. A privatização das prisões sob a ótica do direito administrativo. Editora Revista dos Tribunais: São Paulo, 1995.

RIBEIRO, Armando Lúcio. Privatização (Terceirização) dos Presídios. Disponível em http://www.mp.rn.gov.br/artigo/caops/caopjp/teses/privatizacao_presidios.pdf.

ROJAS, Francisco José Villar. Privatizaciòn de Servicios Públicos. Madrid, 1993.

RT, 1995.

RUSSEL, C.K. Privatizatio of prisions - "New Law Journal. Apid" .

SANTOS, Jorge Amaral dos. As parcerias público-privadas no sistema penitenciário brasileiro. Jus Navigandi, Teresina, ano 14, n. 2269, 17 set. 2009. Disponível em: <http://jus.uol.com.br/revista/texto/13521>.

SILVA, Cosmo Sobral da; BEZERRA, Everaldo Batista. A terceirização de presídios a partir do estudo de uma penitenciária do Ceará. Jus Navigandi, Teresina, ano 10, n. 645, 14 abr. 2005. Disponível em: http://jus.uol.com.br/revista/texto/6541.

SUSSEKIND, Elizebeth. Aspectos da política prisional no Brasil. Revista CEJ. Ano 5, $\mathrm{n}^{\circ} 15$. Brasília, dez 2001.

THOMAS, Charles W. in TABARROK, Alexander (org.). Changing the Guard. Oakland: The Independent Institute, 2003.

VASCONCELOS, Arnaldo. Direito, Humanismo e Democracia. Malheiros, São Paulo-SP, 1998.

WACQUANT, Loïc. As Prisões da Miséria. Rio de Janeiro: Jorge Zahar, 2001, pág 32. http://en.wikipedia.org/wiki/Corrections_Corporation_of_America disponível em 19/07/2010 Increased Competition in Department of Corrections Will Lead to Additional Savings , Virginia Viewpoint, June 2003, Geoffrey F. Segal, Virginia Institute for Public Policy 
CCA Provider correções nomeado para a revista Empregos Top List 50 GI Militar de empregadores Friendly

http://en.wikipedia.org/wiki/Corrections_Corporation_of_America -disponível em 19/07/2010

<http://www.transparencia.org.br> . Acesso em 12/10/2010

<http://www.contasabertas.uol.com.br.> Acesso em 10/10/2010

<http://www.depen.pr.gov.br/modules/conteudo/conteudo.php?conteudo=36>Acesso

em 20/09/2010

$<$ http://www.aspra.org.br/index.php?option=com_content\&view=article\&id=523:clippingdiario-130309\&catid=16:deu-na-midia\&Itemid=6> Acesso em 17/10/2010 